\title{
The Dilemma of Determining Urban Administrative Boundary for Land Administration: The Case of Shire Inda Silase
}

Asfaw Takele Feleke ${ }^{1}$

${ }^{\text {'Ethiopian Human }}$ Rights
Commission;osef Tito Street; Guinea
Conakry Street; Africa 'Godana' Street;
Addis Ababa, Ethiopia.
Email: Takeleasfaw279@gmail.com
Tel: +251-0914489574

Licensed:

This work is licensed under a Creative Commons Attribution 4.0 License.

Keywords:

Urban Boundary

Demarcation

Urban Administration

Urban Land Administration

Dilemma.

\begin{abstract}
This investigation is undertaking on the topic of "The Dilemma of Determining Urban Administrative boundary for land administration". Different studies of well-respected scholars address that boundary issue come to realize at the recent times following to the intolerable environmental destruction and other problems which had result due to uncontrolled urban growth. Those studies try to assure that urban or city agglomerations accommodate wide horizontal expansion which in turn puts an effect on the life of Peri-urban farmers, the environment, and the ecosystem to the extent of being not rehabilitated. Many studies point out that the considerable number of environmentalists, planners and city administrators came to stand against sprawl campaign and deal with the demarcation of a boundary on their cities and towns. Many metropolitan and megacities of USA were an exemplary role in practicing demarcation. Different studies also address that, though it is different in kind and importance, an absence of demarcated municipal administrative boundary also come a big concern-able issue to the town and cities of both developed and developing countries. As different studies explained it is this issue which our country starts to worry and deal with. However, cities and towns of ours had not demarcated their boundary yet including the study area of this investigation. Because of the absence of demarcated boundary in the study area, problems like conflicts regarding double ownership claim, informal expansion, etc. widely happen. This is the reason for why the researcher conducts this investigation. The researcher used a descriptive method and employed both quantitative and qualitative approaches. The researcher also used questionnaire (open and closed-ended), Interview (semi-structured) and observation (structured) data collection methods. This study used both primary and secondary data sources. The researcher analyzed and presented results using tables, bar graph and figure. The investigation, therefore, assessed that lack of determining one's boundary had put many problems such as planning over hedge of the town administration with the neighboring 'wereda' administration, conflicts on double ownership claim, destruction to the surrounding environment and the life of other residents, or generally put many problems to Shire Inda Silase town. So, the researcher recommends that the city administration of Shire Inda Silase need to develop collaborative and cooperative work habit with its neighboring rural wereda administration, with Shire Inda Silase city development stakeholders (Such as planning and consultancy office), with other concerned bodies like the Tigray Planning bureau, and with federal governments.
\end{abstract}

\section{Introduction}

Determining one's boundary benefits the specific urban area and its administrative entities in different reasons. Such as: protecting urban sprawl, appreciation of compact development, or for saving the city or town from boundary case conflicts with its neighbouring city or town, or rural administration. In Ethiopia this time, though there had been a recent beginning on ratifying a policy directive, issue not given adequate attention on boundary demarcation of towns and cities. The researcher was found this issue as too critical to the country in general and Shire Inda Silase town in particular, set his time and knowledge made an investigation on it. 
This investigation, thus, conducted on Shire Inda Silase town to assess the impact of boundary Demarcation on land Administration.

This Thesis, as a final report for the investigation, contains five chapters. Chapter one contain background, problem statement, general and specific objectives, significance, scope and delimitation, as well as study area description and limitation of the investigation. In Chapter two it describes or reviews significant literatures studied by different scholars. Chapter three specify suitable and easily capable methodologies. Chapter four includes organizing and presenting as well as interpret and analyze the data which has got from the ground (research area). Finally, recommendation and conclusions of the findings are described on chapter five.

\subsection{Back Ground of the Study}

Currently, Urbanization is going as one of the extreme cases in land use and land cover. $1.2 \%$ of the earth's land is assumed to be urban and this is expected to rapidly increase in the near future (Shepherd, 2005 cited on report of panda Jagabandhu research staff, September 30, 2010-March 31, 2011). According to this report, it is estimated that by the year $2025,60 \%$ of the world's population live in cities and as a result there will be a possibility of significant increase in the human activity [for instance sprawling and squatting] on the urban environment.

On both developed and developing countries, It was true that, urban expansion was deliberately took With the transportation advances of the 19th and 20th centuries, however, planners were led to make containment a priority, in the service of large-scale government initiatives on resource allocation and quality of life (Babbitt, 2005 Cited in Reid, Rolf, and Don (1990-2000)).

However, sprawling, as some scholars suggest (Lopez, Adelaja, and Andrews 1988 cited on Marin (2007)) can put an adverse economic effect. For instance: by creating externalities, expectations, and uncertainties on farmland lowering the agricultural products [coffee. for instance, in our context] and in turn minimizing the national GDP.

These may lead to conversion of farmlands to urban uses or impermanence syndrome, which results in vacant agricultural lands, disinvestment in farming, and lower agricultural productivity. Other scholars like (Ewing, et.al, 1998 cited in Iestyn, Helen, and Suzanne (2010)) indicates that Across the nation, growing numbers of communities are discovering links between urban sprawl and a wide range of problems, from traffic and air pollution to central city poverty and the degradation of scenic areas. As more civic leaders take steps to ameliorate these costs, they are in increasing need of meaningful information about the characteristics, extent and consequences of sprawl. So, from these scholars' suggestions we can understand that an urban boundary demarcation had been becoming essential. Unless there should be a containment towards urban sprawl (which is demarcation of urban boundary), the horizontal growth may bring its own effect on the town or city in different dimensions.

The term Boundary, according to on line Dictionary, is a line which determines the limits of an area, bound or edge. An urban boundary, in this context, is a line that determines the limit of an urban or an entity that specifies the bound or edge of an area called urban. For instance: a line drawn between urban and rural lands defining the limits to which the urban area will grow.

According to Staley and Mildner (1999) Benefits of [having or determining] boundary, more specifically, include: induce more-compact development close to existing urban areas, create a definable urban/rural edge to protect scenic vistas, preserve farmland to protect open space, protect the local agricultural industry from encroachment by non rural land uses, promote infill in already developed areas and foster the revitalization of the county's major city, and Provide for efficient public services near already urbanized areas. But the question is what kind of Boundary is required?

There are three types of boundaries. These are: 1, Urban Growth boundary 2, Municipal administrative boundary or an urban Service boundary; and 3, Planned boundary or a green belt (Pendell, Martin, \& Fulton, 2002). Simply defined, an urban growth boundary is a regional boundary circumscribing a metropolitan area, which is used by governments to distinguish areas for urban development from areas to be preserved as rural or wilderness. In theory, UGBs control expansion onto farm and forest lands, while concentrating development to be more efficiently served by urban infrastructure (Lopez, Adelaja, and Andrews 1988 cited on Marin (2007)). However, this investigation had issued on Municipal Administrative Boundary and its impact on land Administration. Municipal Administrative Boundary, according to Pendell et al. (2002) denotes the edge of an urban service area and is denotes a line beyond which a city has decided that its infrastructure typically sewer and water - should not extend. According to Pendell et al. (2002) this will encourage higher density and infill development within the urban growth boundary, while helping to maintain the rural character of areas lying outside the boundary. 
Municipal boundary had come as major concern of the city managers, planners and environmentalist as to what extent that cities would expand horizontally. Boundary demarcation processes, though it was only Urban growth boundaries (UGBs), were first put into practice in the United States after these failed national attempts at land use planning (Gatanaccio, 2008 Cited in Ying, et.al, 2015).

Though it is a recent phenomenon, today most Countries of the world goes greater jump in taking reaction towards controlling sprawl by setting containment policies and boundary demarcation strategies as a response focusing on Smart growth and creating Compact growth of cities and towns. USA Cities: such as Oregon and Washington (Pendell et al., 2002). Oregon was the first and remains among the few to make UGBs a key element in their state-wide land use plan.

When we look to the case of Ethiopia the issues of boundary, however, seen as it was left or set aside out of imagination just as worthless thing and rather on behalf promote undetermined growth of towns on their peripheries (Isaac, 2009). All urban entities of Ethiopia, today, largely expand towards the peripheries. Agricultural lands are conquered through the effect of urban sprawl, forest and the ecosystem in general becoming put to greater distraction, because of the actions of the squatter settled people on the urban fringes. The same thing had true In the case of Shire Inda Silase. Shire, especially towards the two distinct parts of the town called 'Adi kentibay' and 02 kebeles, observed this problem more (personal Communication with Gidey on December 19, 2012). So this papers explore the current situation existed on the ground and then tends to put good workably multifaceted recommendations and directions so as enabling the ULGA of shire Inda Silase come up with better solutions towards the existed problem.

\subsection{Statement of the Problem}

Today's cities and towns, as the researcher describes above, adhere towards delimiting their growth, planning and administrative boundaries. Instead tend to compact development and smart growth. This is in order to minimize the adverse effects of uncontrolled horizontal growth (Lopez, Adelaja and Andrews 1988 cited on Marin (2007)). Environmentalists and governments and city administrations also worry about it much and set different policy directives. For instance: Ethiopia since 1999 sets a policy direction (called national urban development policy) so as to control illegal expansion of towns and cities and the proliferation of towns in the middle of nowhere eating farmlands have been on the increase in all the four regional states (ECSNCC (Ethiopian civil society network on climate change), 2011 cited on UN-Habitat (2012a)).

However, expansion and growth of towns and cities in Africa perhaps especially in Ethiopia Is uncontrollable issue. Towns are expanded horizontally to the extent of having an effect on land administration and even beyond makes influence on the boundaries agricultural land and the ecosystem in general (Isaac, 2009). Like it was in developed country in which one's was appreciated and soon widely condemned, today's cities and towns of Ethiopia sprawl horizontally to the extent of having an impact on the surrounding agricultural and the ecosystem. For instance: when we look to the case of Addis Ababa, over the study period of one study, built-up area has increased by $5.04 \mathrm{~km} 2$ per annum against $5.20 \mathrm{~km} 2$ per annum decrease of forest cover areas (LiulSeged, Gete, Dawit, Fitsum, \& Andreas, 2011).

According to Isaac (2009) contemporarily knowledge of Urban Management Masters Program (UMMP) has failed to tackle the negative impact of urban sprawl or urban expansion on the livelihood of small scale farming households. Because of the uncontrollable sprawl, the land use right disputes have been going to become too much worse than ever specially at the urban boarders in areas where the use and administration of that particular land is found belongs to the rural areas, as far as housing issue is more critical to the existence of each citizens of the country.

For instance: In Jima town there is a series conflict between the municipality and the displaced farmers from their farmland because of urban expansion (Isaac, 2009).

In addition to this, when urban centre expands and interfaces with rural population in urban periphery area who has been engaged in farm agriculture before expansion, then, they become insecure in terms of their livelihood and turned to deplete the forests in the urban area (Sewunet, 2008).

Even though there are recent initiations to concern and make a forum to mitigate the problem by Ethiopian Government and other concerned body like environmentalist, there are no measures taken to control and if possible to stop the actions of the informal squatters and in some case provision of land by the municipals around the urban infringes.

Mostly, the worse thing repeatedly happen for towns and cities regarding to absence of having urban or town boundary is glaring conflicts on claiming double ownership over the same area. Shire Inda Silase, regarding to this issue of boundary demarcation and protecting the due effects of urban sprawl, is I can say surely at the beginning.

There is a great expansion of informal squatting settlement around the periphery areas to all sides mainly towards the east and west direction of the city in which the rural administration claims of ownership rights (boundary and related issue study report of the municipal, 2012). 
According to Gidey Tadesse (Employees of ULGAs), because of the continued conflicts he said that "even professionals like me claim no after they come and sponsored by the ULGAs here to learn and after they graduate claim no while they placed o the land and related issue of the town". This happens, as he informed me, because they scared of dealing with the issue of land ownership rights as a result of conflicts happen at around the boarder of the town, specially, along the two kebeles (named 'Adi kentibay' and 02); there was a disagreement in between the town municipal and the neighbouring rural Administration.

So far no studies have been conducted on this problem, the researcher had triggered to explore as well as study the existed boundary issue of the town and the due effect of determining urban boundary demarcation on land administration.

\subsection{Objective of Study}

\subsubsection{Main Objective}

This investigation intend to assess over all existing issue of boundary and it's Impact on land administration

\subsubsection{Specific Objectives}

Specifically, this study had intended to address the following objectives:

- To assess the existing condition of the shire Inda Silase boundary demarcation;

- To investigate the cause of conflict between the ULGA and the surrounding rural area administration;

- To assess the factors which made to delayed demarcation of boundary on Shire Inda Silase town;

- To assess the impact of lack of demarcated urban boundary on land administration;

- To identify the opinion of experts and consultants on the importance of boundary demarcation

\subsection{Research Question}

In advance of the above objectives, this investigation will goes to answering the following questions:

- To what extent the existed boundary problem sounds on Shire Inda Silase?

- What are the factors causes for conflicts and to which extent area they made glaring effect, more specifically shown on the border lines?

- What are the factors hinder boundary demarcation process?

- What land related problems would occur as a result of a loosely demarcated boundary?

- What would be the opinion of experts and consultants on the boundary demarcation process and its importance bear for land administration?

\subsection{Significance of the Study}

Helping learners being aware about the impact of urban boundary demarcation, this investigation have a policy and administrative implications. Meaning Administratively, being as a guidance helps the ULGA to be informed about the out coming impact of demarcation, then, they will intended to stop urban sprawl and in turn protect the coming tomorrows problems. If so this becomes administrative issue. Second, it Impart the above stated objectives touch the urban policy rationales; this study puts a significant to the effective and sustainable implementation of urban policy issue. In this case, therefore, would have policy implication.

\subsection{Scope/Delimitation of the Study}

Though unlimited boundary growth or uncontrolled urban sprawl had been become the issue of all urban centres of Ethiopia and in turn coming be the most headache of the government at general and the urban managers in particular; this investigation have conceptual and geographic delimited. Conceptually:- it only had intend to investigate the implication of demarcating urban boundary on land administration in shire inda silase town or it only had intend to put important suggestions which would probably use for the today's policy regulation directives goes on approval process. It didn't goes beyond as to condemned and or took corrective measures on the previous actions of the ULGA of the Shire Inda Silase, or as to gone to the extent of setting policy regulations or directives. Geographically: - this study delimited to the administrative jurisdiction of the Shire Inda Silase ULGA and the rural wereda, perhaps specially on the green areas, which causes it to wards conflict and disputes.

\subsection{Description of the Study Area}

This indicates condition in which the geographic and administrative location of the study area looks like or lies on. 


\subsubsection{Geographic location of Shire Inda Silase}

Shire (the short name of Shire Inda Silase) is Located North-western zone of Tigray region lying on two major tourist destination places.

Which is Semen wards from Gondar and the Semen Mountain as well as north-western from the Axum town. Its road net work and surrounding agricultural production potential make Shire to be an important economic zone of Tigray (Deborah \& Tadesse, 2006).

According to Coordinate system, Inda Silase (the other name given to Shire Inda Silase) lies at an altitude of 1900 meter (Nial, 2005) as well as it found 1406'18" North and 34 17' 4" East (Satellite Map finding). Shire Inda Selassie is located 1064km from Addis Ababa via Mekelle. According to Google satellite Image the layout of Shire Inda Silase Town Looks like as follows (See the following Figure).

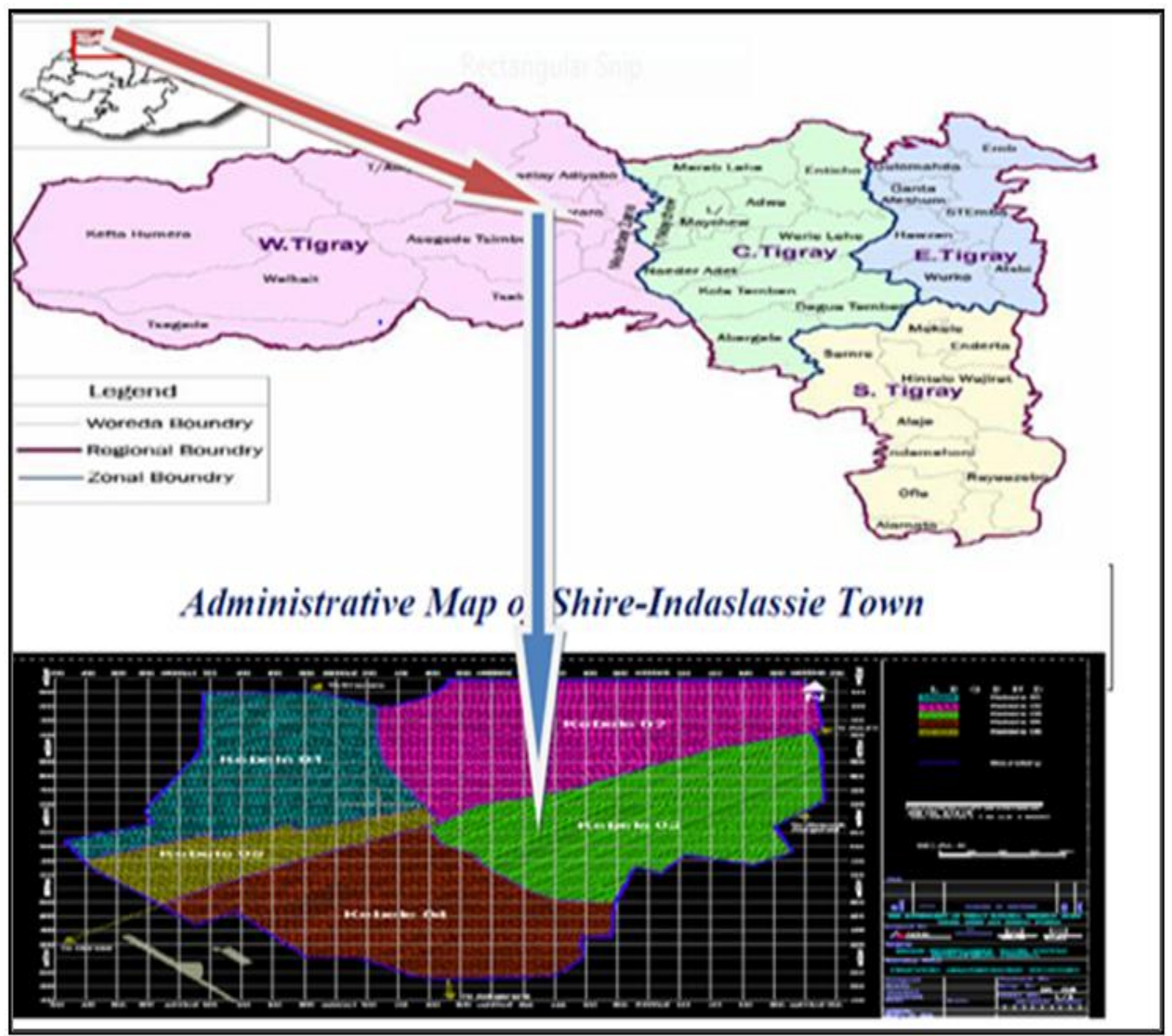

Figure-1.1. Map of Shire Inda Silase town when it is seen in reference to the 'Tigray' region and NW-zone.

Source: Adopted from the Shire Inda Silase Town Administration office, 2013.

The present municipal administration coverage of the town, even though didn't clearly known where starts and ends, habitually understands as it encompasses an area of about 760 hectares, of which approximately 462 hectares have been developed. The total population has grown from 36,700 in 2002 to about 44,000 in 2005 (or, about 20 percent over the three year period). Inda Selassie has had economic and political significance only in very recent times, a consideration important for interpreting the history of its surrounding landscape (Nial, 2005).

\subsubsection{Administrative location of Shire Inda Silase}

Shire Inda Silase is one of the 12 urban administrative towns of TRNS established its organizations through the proclamation of TRNS (TRNS proc. No. 65/2003 or 65/1995 E.C) (Deborah \& Tadesse, 2006). It is surrounded by; 'Tahtay-Koraro' rural administration woreda. It is the capital city of N-W Zone 
administration as well as Woreda administration of the town; it serves as centre of the rural administration Woreda Tahtay-Koraro. In its administration jurisdiction and the town has divided in to five local administrations (Kebeles).

According to the Shire Inda Silase municipality office urban land department the most conflicting area in which urban boundary conflict mostly happen are those Ares seen by Light Red colour in the following picture or map. The surrounding kebele which is mainly affected by the conflict with the Urban infringe is pointed by point 'A' and the town is focused by point 'B'. (See the following map)

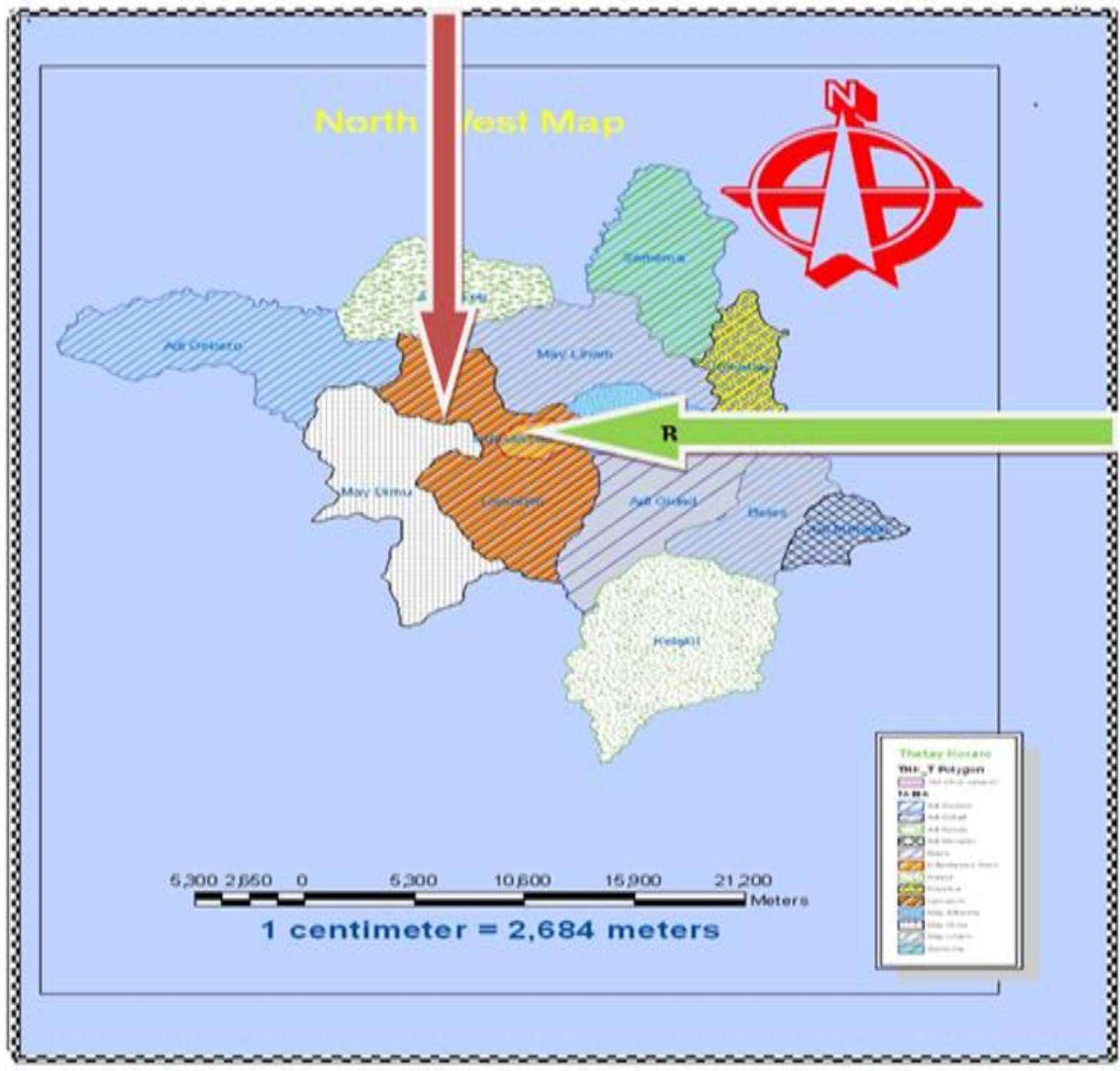

Figure-1.2. Thematic Spatial map of the conflicting areas taken as a case study.

Source: Shire Inda Silase ULGA, Department of Urban land Deve't \& Mang't.

According to Gidey Tadese (employee of Shire ULGA), from among the wide coverage of the town the specific areas in which the problem of boundary disputes highly shown are the two kebeles named 03 or Adikentibay towards the Wek'ar Duba and 04 kebele towards Adi-Ademay rural kebele surrounding areas (personal communication on December 19, 2012). The more conflicting area which are taken as a case study area are those who are shown on the following photos ' $\mathrm{A}$ ' and ' $\mathrm{B}$ ' merged on the total area map of the town taken from Google (see the following picture deeply). 


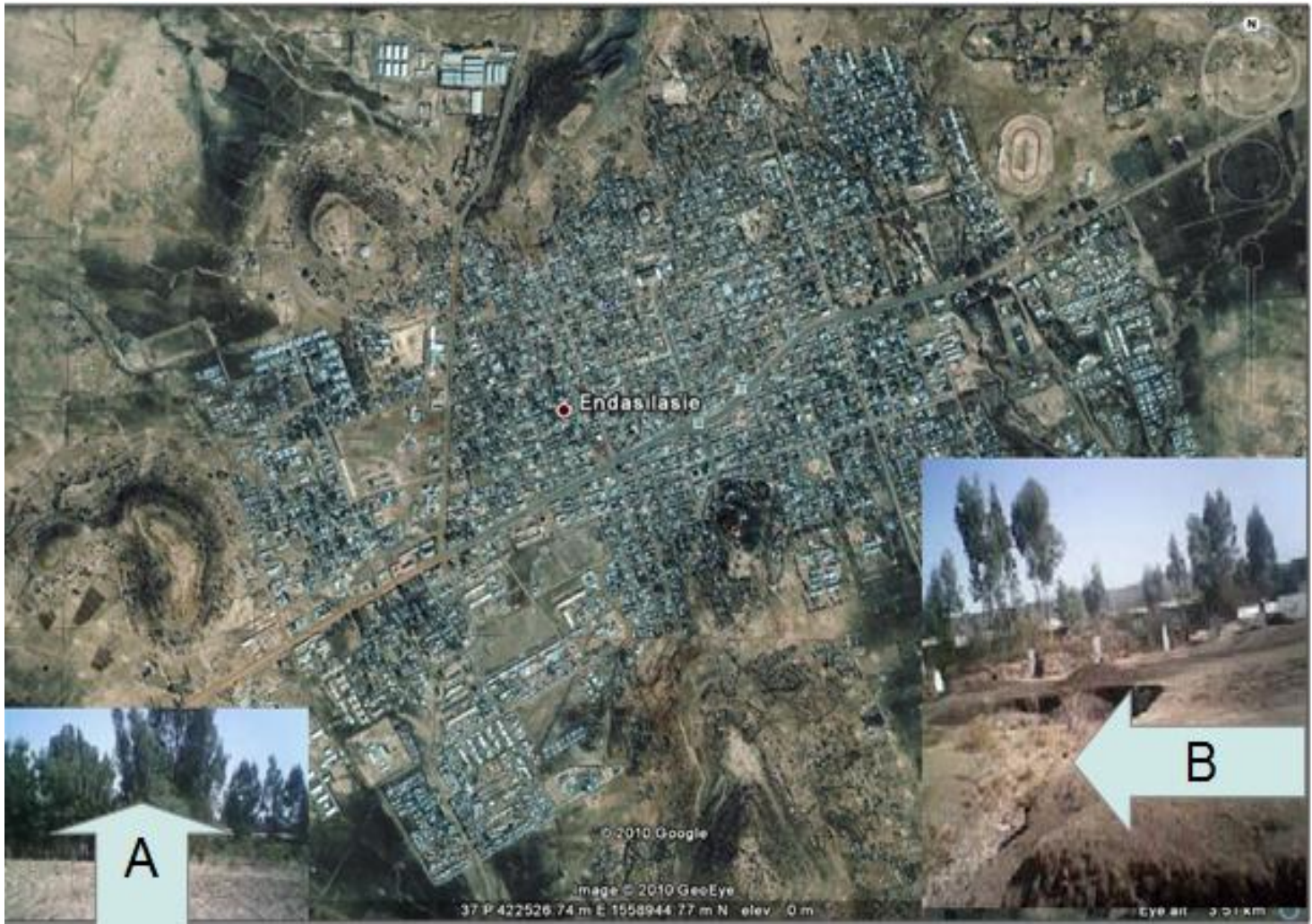

Figure-1.3. Administrative Location of Shire Inda Silase in reference to Google Satellite Image.

Source: Shire Inda Silase ULGA \& Field Survey.

Point ' A' Shows the sample photos taken at the case study area of 'Kebele 04' and point 'B' Shows the sample photo taken from the case study area of 'Kebele- 03'

\subsubsection{Demographic Characteristics of the town:}

According to Central Statistical Agency Addis Ababa (2012) population projection, the town has a total population of 57,198 . This projection indicates that, including the natural and migration increment, 2,704 people have been increasing every year

\subsection{Limitations of the Study}

During this study, certain constraints had encountered .First, lack of adequate and compiled data regarding to the existing status of boundary and its related issue on the past years in the town. Some of the required information such as reports about the impact (could positive and negative) or if there were some benefits gain or not due to the loosely demarcated boundary condition which is found in the Land department municipal office of the town is very neat and wired. In addition to this, studies which have done on related topics and references are very rare and hardly found. Therefore, the aforementioned limitations limited the researcher from a better effective and efficient analysis and gap filling on the issue rose. Finally, there was inadequacy of finance.

\subsection{Summary}

Today's horizontal Expansion of towns had put glaring effects on towns or cities of Ethiopia to the extent making complex and difficult the land administration aspect at particular and to the town in general. It had endured different multi-faceted effect on the livelihood of the farmers, the town dwellers found at town periphery, at the surrounding environment, and ecosystems. Planners, town administrators, environmentalists, and governments had been start Understanding the effect of the problem. Some countries had goes great jump in dealing with this problem. Ethiopia, in this case is found in the position of studying and founding solutions towards the problem. The researcher's study area was also at this circle. However it didn't stack exactly to this critical issue yet. So, the researcher had investigated on this problem. The researcher had set out general and specific objectives as well as critical researcher questions. He describe the geographic location of the area and at final predicts what challenges could be might faced with in the investigation. The remaining works of the researcher explained in the next chapter. That means the research Methodologies, Findings, and Conclusion and Recommendations of this study will described in the preceded chapters: Chapter Three, Chapter Four, and Chapter Five respectively. 


\section{Literature Review \\ 2.1. Introduction}

This chapter contains the discussion of theoretical and conceptual issues used to frame the investigation. It explores the urban boundary demarcation trend of other countries and the cities of Ethiopia. It also tend to explore whether or not the problem analyzed before inside or outside the study area which means it goes to the extent of identifying the knowledge gap on the problem. In addition to this, section explores the Ethiopia's housing and land use policy approach. Finally it assesses the trends of what factors causes to not demarcate and/ or marking a clear cut demarcation on the periphery growth of urban centres.

\subsection{Theories and Concepts of Urban Boundary Demarcation}

This refers to the concepts and theories in which boundary demarcation and its impact adapted all over the parts of the world in long time span. This section includes two sub-sections, concepts as one section and theory as another section.

\subsubsection{Concepts of Urban Boundary Demarcation}

A boundary is "A thing which serves to mark the limits of something; the limit itself, a dividing line" (Jean Oxford Dictionary, 2009 cited in Terrier (n.d)). This concept is a wider concept and constituents of three terms (urban, boundary, determining). An Urban- is according to the draft of boundary demarcation model directive (2012, Amharic Version), refers to an area where municipality or Town Administration is structured that contains 2000 and above population size among which $50 \%$ is occupied on non-agricultural activity. Whereas boundary is the notion of limits, lines or boarders (Avis, et.al. 1983) cited in Smart Growth AmericaRegistered Nurses association of Nova Scotia (2002)). Determining, on the other hand, is the process of deciding or specifying the limits of something (Online free dictionary, 2001). From these definitions urban boundary demarcation, therefore, refers to the processes of determining an area called urban from the next area or neighbouring administration. Different researchers with their writings express variously for by what urban boundary means.

As I tried to show in the background section, there are three types of urban boundary. These are: 1 , Urban Growth boundary; 2, Municipal administrative boundary or an urban Service boundary; and 3, Planned boundary or a green belt (Pendell et al., 2002). Three of them are part of the urban growth containment or management policies, but they are different in concept. The Urban Growth Boundary, according to Gatenaccio (2008) Cited in Ying, et.al, (2015) is a regional boundary circumscribing a metropolitan area and distinguishing areas for urban development from areas to be preserved as rural or wilderness is widely seen as a promising tool for reining in urban sprawl. An urban growth boundary is a line drawn between urban and rural lands defining the limits to which the urban area will grow. Planned boundary or green belt boundary is usually refers to a band drawn fairly tightly around a city or urban region that planners intend to be permanent or at least very difficult to change. In most cases, greenbelts are created by public or non-profit purchase of open space lands or of development rights on farmland (Pendell et al., 2002).

Whereas administrative boundary or an urban Service boundary as Pendell et al. (2002) address denotes the edge of an urban service area and is denotes a line beyond which a city has decided that its infrastructure typically sewer and water - should not extend. According to these writers

"In many metro areas, urban service areas support a "tiring" system - that is, a system that directs public infrastructure into new areas in a particular sequence - in order to eliminate "leapfrog" development, encourages orderly urban expansion, and reduce the cost of public infrastructure. Urban services are also often tied to adequate public facilities ordinances (APFOs) - tools adopted by municipalities and counties to restrict or prohibit new urban growth unless that growth is served by roads, public water, public sewers, and other urban infrastructure."

This investigation and the review literature part both deals only around the third type of urban boundary.

\subsubsection{Theories on Urban Boundary Demarcation}

Regarding to demarcation of urban boundary there are two contradictory theories. Of course I can say the whole world, prior to the late 20th century, had been supported growth of cities and metropolis towards their sprawl. For instance: According to periodicals of one study made at NTU traces that before the late 20th century for about 3 decades urban sprawl or growth of urban areas towards their periphery is seen critical. During this time as David (2006) explains, the concept of UGBs has come under criticism and scrutiny over the past decade and is considered controversial by some. This is because of the substantial rise in housing prices, especially on the West Coast of the US in this period. According to the critics of the proponents of urban sprawl, limiting the supply of develop-able land through UGBs puts an upward pressure on the price of existing develop able and already developed land, leading to higher housing prices.

Even though it is a recent trend, however, the supporters of the concept or advocates of URGs counter this critique by pointing out that housing prices have increased similarly across the country and according to economic analysis, farmland appreciated similarly to the other land. Moreover, they defend the idea by point 
out evidence suggests that Portland's housing market is still more affordable than other West Coast cities. Today this theory highly provoked evidences of phenomenon on the environment, infrastructure and even in land administration of a town, etcetera, resulted through uncontrolled urban sprawl. Among the advocates of urban boundary demarcations, Pierre (2003).

In his journal article called smart urban growth, tried to show how the uncontrolled urban growth creates impact on climate (air pollution) high cost of development, deteriorating quality of life, environment, and perhaps specially on land administration of the town and intern show how smart growth can implement within the prevailing political, economic and value environment. Generally any of the today's study witnessed that urban boundary demarcation or boundary limit growth of urban areas is most selected one in terms of in rolling growth in harmony with environmentally sounded built environment.

\subsection{Trends of Metropolitan and Big Cities on Determining Urban Boundary and the Observed Outcome:}

According to, Queensland Government (2016) addressing and locating rural properties, in countries like Australia, is a major problem. Examples of people giving directions such as "turn left at the old gum tree and then right at the forty-four gallon drum" are common place. These old methods relied on local knowledge and are incompatible with today's demands for addressing protocols. As a result, the allocation of addresses to rural properties has become a priority.

The urban boundary demarcation, in most case and in most areas of the world, is a recent phenomenon or trend. That means until recent, since the past 20 years and especially in the last decade of this century, many researches are examined the impact of urban containment policies and on the implementation issues that arise from their use. But this research is far from definitive (Pendell et al., 2002). Though it is only in urban growth boundary, however, there are a number of countries or big metropolis who accomplishes a great jump in boundary demarcation compared to other cities and towns [like in Ethiopia] who are recently awake from their sleep. Samuel and Gerard (1999) addresses that "More than 100 cities and counties have adopted some form of a growth boundary a limit on land development beyond a politically designated area to curb sprawl, protect open space, or encourage the redevelopment of inner-city neighbourhoods. State-wide mandates for growth boundaries exist in Oregon, Tennessee, and Washington."

As some writings shown evidences the first in taking actions and the most popular cities regarding to demarcating their urban boundary are two cities and two States of USA Such as: Portland of Oregon, and Las Vegas of Nevada. For instance: As (Ishani, 2012 Cited in Bagchi (2012)) addresses that, every city in Oregon has a boundary line enclosing lands that are eligible for urban development. These urban growth boundaries (UGBs) separate "urbanize" land from "non-urbanize" land. Today's urban growth boundaries (UGBs) are an increasingly popular approach to growth management.

Washington and Tennessee mandate their use; Florida encourages them; and Maryland and California have been doing them for decades. In South Carolina, urban growth boundaries, or extraterritorial jurisdiction is permitted under State Planning Enabling legislation, but there are no state or local statutes to require urban growth boundaries. In some cities like Auckland are still too late to conduct the issue this time. Because from their plan of 2013 or now which sets on August, 2012 they are found only to collaborate the definition of UGB in assuming that they can accomplish it on 2040 (Auckland Council, 2012). All the above trends are describing towards the UGB only. Therefore, determination of Administrative boundary is a studied issue. Or it is to mean that There is a research Gap regarding to this issue in Developed nations.

\subsection{Trends of Developing Countries on Urban Boundary Demarcation}

Here, I can say that there is no well developed and implemented UGB practice neither in other African countries nor In Ethiopia, though the situation requires on the ground one. For instance: The ministry of urban and construction launches studying the problems resulted through the uncontrolled urban growth and/ or boundary less urban sprawl and in turn on a process of setting policy directives and regulations on determining urban boundary (Ministry of Urban Development \& Construction (MoUDC; Amharic Verions), 2013). Regarding to this issue neither studies nor is works taken. So there is a Knowledge gap regarding to this issue again in our country.

\subsection{Processes of Determining Urban Boundary}

In determining urban boundary it is better to know important procedures so at to avoid the urban disputes or so as to harmonize the competing interests of the two parties. Countries regarding to their context and the type of boundary which they want to develop differ one from another. Even from one organization to another organization. For instance: According to the FHWA (2003) the 2000 urban cluster and 2000 urbanized area boundaries will be fixed by responsible State and local officials in cooperation with each other, subject to approval by FHWA. According to this hand book it is important: 
- To have important tools Such as the 2000 census boundary maps, and land use maps showing areas of growth that can be used to predict areas of future growth;

- Adjusted urban boundaries, as a minimum, encompass the entire urban area designated by the U.S. Bureau of the Census (Census boundary);

- Census boundaries should be expanded so as to smooth out irregularities, maintain administrative continuity of peripheral routes, and encompass fringe areas having residential, commercial, industrial, and/or national defence significance. Transportation terminals serving the area such as airports and seaports should also be included within the redefined area if they lie within a reasonable distance of the urban area boundary that would otherwise be selected; etc.

When we come to the case of Ethiopia the processes of conducting demarcation processes is done through the procedures set by the Ministry of Urban Development and Construction (MoUDC) head bureau. According Ministry of Urban \& Construction (MoUDC; Amharic Version) (2012) when demarcation process are taken, it is important to follow the following procedures or steps. These are:

o Formulating of the regional administrative urban boundary observation implementer or enforcement organ, could be committees which consists of members from different positions. Such as: the regional president, the region land development and management officer, the region rural land administration officer, etc;

o Formulating of the zonal urban boundary observation implementer or enforcement organ could be a committee consists of the above sector officials but in zonal levels; etc.

So, in making or determining urban boundary requires important procedures to the extent of avoiding disputes among the stakeholders

\subsection{Implication (benefits) of Demarcating Urban Boundary}

Administrative boundaries are not controlled like national boundaries, although they may be visible by way of signs and changes in the landscape and development structure (Frank 2001a cited in Eagleson, 2002). The primary role of administrative boundaries is to segment space into separate areas within which agencies are able to administer resources. The theory of administration is concerned with how an organization should be constructed and operated in order to accomplish work efficiently. A fundamental principle of administration follows almost immediately from the rational character of "good" administration. It is that when choosing between several alternatives involving expenditure, the method selected should always result in the greatest accomplishment of administrative objectives (Simon et al., 1994). As a result of careful administrative decision-making is needed.

Administrative boundaries are perhaps the source of the richest information, and they may be the most thoughtfully drawn of all types of boundaries, reflecting many different factors (e.g., history, aesthetics, defence, resources, etc.) that have been weighed and ranked in importance (Marquardt \& Crumley, 1987) on a theoretical level, administrative boundaries represent both impediments and opportunities. For example, the boundary effect may occur if homogeneous regions are cut by an administrative boundary (Rumley and Minghi 1991 cited in Serryn (2002)). The boundary effect is derived primarily from differences in policies, services (e.g. policing, schools and health care) and tax levels on either side of the boundary. As a result of the boundary effect, people develop different attitudes towards the boundary depending on whether they see it in a positive light and whether they see themselves as being on the "right" side of it (Storey 2001 cited in Serryn (2002)). An example of boundaries affecting peoples' perceptions is reflected in real estate prices, which often fluctuate based on suburb boundaries.

Administrative boundaries have a location or territory, and people belong to them. People interact with the space within the boundary limits and, as a result, the boundary affects them in some way. The locations of administrative boundaries can be constrained by the physical environment but are not determined by it.

The specific status of an administrative unit can lead to preferences about the spatial properties of its location: to be connected (to support interaction and communication), and for effective administrative purposes not to overlap. Administrative boundaries can start and cease. They can change over time in terms of who belongs to them, their location and their functions within different organizations and social structures (Eschenbach 2001 cited in Serryn (2002)). There are a number of advantages to using administrative boundaries for the collection of data. For example, once the administrative boundaries are established, the data is easily collected and efficient to store. Even in light of technological advancements, other forms of geographic data - such as address point and line data are still relatively expensive to produce, difficult to manipulate and require large amounts of memory to store (Rajabifard and Williamson 2001a cited in Serryn $(2002))$.

\subsection{Land Administration Concept}

This section deals about two sub-sections. Section one deals on concept of land registration. Section two about the land registration system. 


\subsubsection{Concept of land Administration}

Daniel (2011) Cited in UN-Habitat (2012b)) address that urban growth is an inevitable outcome of economic and social functionality of cities and towns. This being the case on one hand, on the other, the rapidly growing urban population has become one of the most critical problems facing both central and local governments especially in developing countries. On one hand as this writer addresses "In most Sub-Saharan African countries, governments have been acquiring land from the Peri-urban areas in order to accommodate urban expansion processes. As efforts are directed to acquire land for urban expansion in the Peri-urban areas through compulsory land acquisition, an analysis of the implications of the same to the livelihoods and interest of the Peri-urban households is wanting"

On the other hand The Federal Constitution of Ethiopia cited under Article $40(1)$ and $40(8)$ states that "the farmers who hold farmland have the right not to be displaced without just compensation from their land". In addition, as Isaac (2009) address "Long lists of evidences from Ethiopia (Tegegn G/Egziabiher and Daniel, 1997) and many scholars from aboard (Setterhwite and Taxholi 2003, kamtere, Tostensen and Tedeten 2001) stated that urban expansion has many negative [socio-economic and environmental] on the Peri-urban farmers and the farmers in the Peri-urban area". So as to make in harmony with these contradictory issues it is better to have the land Administration paradigm.

When we look to the concept of land administration, scholars had not made one single definition for by what land Administration mean. As (ECSNCC, 2011) address "Different organizations define land administration in different ways. Whatever the differences in definitions however, many agree that a good land administration system guarantees security of tenure; provide security for credit; develop land markets; environmental protect state/communal management; etc. lands; Furthermore, reduce it is land asserted disputes; that support sustainable development cannot be attained in the absence of a functioning land administration."

\subsubsection{Land Registration System}

A land registration is one important aspect of land administration. According to UN-Habitat (2008) a Land Register is a set of records of rights in land. It is the result of a process known as land registration in which the evidence of ownership of rights to the land is recorded and in many countries guaranteed. A right is something to which some person or group of persons is entitled. The function of land registration is to provide a safe and certain foundation for the acquisition, enjoyment and disposal of rights in land. It creates security for title to land and facilitates and supports the wider land and mortgage markets.

The process of land registration should provide order and stability in society by creating security not only for landowners and their partners but also for national and international investors and moneylenders, for traders and dealers, and for governments. The system must be impartial and those who operate it must be free from any conflict of interest. Although systems of land registration are frequently directed at protecting the interests of individual landowners, they are also instruments of national land policy and mechanisms to support economic development. Land registration system has a great role while boundary demarcation is made. Because it helps to identify which land is within the urban territory.

\subsection{Inter Municipality or Urban-surrounding Rural Administration Conflict}

According to the constitution of republic of Kosovo Article 3 Administrative Boundaries Municipalities shall be the administrative boundaries of Cadastral Zones comprising the territory of the municipality where it borders a neighbouring municipality comporting with the administrative boundaries of Republic of Kosovo. According to (MoUDC, 2012: Amharic version), Administrative Boundary municipality refers to a boundary that specifies the area or region of one administrative town as well as differentiates it from the next urban municipal boundary or rural administration. Disputes are happen in case where the one municipal administrative unit tries to occupy land beyond the boundary of its delimitation or in case there is illegal formal settlements such as sprawling and squatting on along the edge of the Municipal administrative boundary.

\subsection{Metropolitan Conflict Governance}

The distinction between government and governance is emphasized in much of the contemporary work on local politics and public administration. At a local level, governance encompasses more than city or county governments, it includes voluntary, not-for-profit and private organizations as well as intergovernmental linkages (Richard, 2002 Cited in Eric, 2012). Worldwide Metropolitan regions (also referred to as "urban regions" or "city regions") are rapidly becoming the predominant form of human settlement (Jeffery, 2002). Worldwide urbanization has given rise to the global phenomenon of geographically extended metropolitan regions.

This chapter focuses on governance of these settings, governance being defined as "actions and institutions within an urban region that regulate or impose conditions for its political economy" (Sellers 2002 cited in Espone-Committee, 2004). According to (Oakerson, 1999 and Parks and Oakerson, 2000 cited in Kiyako (2012)) not many years ago such a statement would have been dismissed as preposterous except for those few metro-areas with something approaching a consolidated metropolitan government. It is now more 
widely accepted though far from universally understood that metropolitan governance can and does occur without metropolitan government and that it can be effective even when a metro-area is highly "fragmented" among a large number of small municipalities

De facto metropolitan borders push, thus, farther and farther out into the surrounding rural area. At the same time, improved transportation and communication technologies have greatly increased the mobility of employers and residents. Especially in developed countries, clear dichotomies between city and country-side have given way to dispersed, Polly centric patterns of settlement and economic activity. Many developing areas, such as the Pearl River Delta of China, manifest a similar evolution. The problem of horizontal governance across an extended area confronts all of these urban regions. Settlement and economic activity frequently expand across institutionalized boundaries, and beyond the reach of stable, pre-existing governance arrangements (Jeffery, 2002). The question here is what if there are no cooperative actions and integration among the governance of this metropolis would result at the expense of high sprawling action is existed? According to this writer this phenomenon presents several potential problems:

- Absence of territorial controls and guidance: Urban spread can be limited and restricted only by cooperative action among the affected urban areas. Local governments must look beyond their parochial vision and strategy, and make at least a minimal effort to acknowledge and accommodate this crucial spill over dimension;

- Shortcomings in management capabilities and experience: Small government units find it difficult to attract and develop the administrative and technical resources required for territorial management. Pooling resources could provide increased efficiency and economies of scale;

- Lack of structural consultation for solving common problems: Collective action by local governments is still the"

To solve these and the like scenarios, working hard and in turn have strong and good Metropolitan Governance unquestionable mandate of the governments of local at individual and the country in general. For instance: (UNDP discussion paper, 2007) address that Strengthening local Governments and improving local governance arrangements through some form of

decentralization has been a policy priority for many countries, in a variety of political settings and various attempts have been made to issue guidelines to steer the decentralization process in both developed and developing countries. Strong local governments and inclusive local governance arrangements are also increasingly seen as essential building blocks of the peace building process in post-conflict environments. However, while early support to strengthening some form of local government is crucial for delivering peace-dividends, international support to local governments and other local development actors, backed by sufficient field presence, has not always been timely and commensurate (UNDP discussion Paper, 2009).

\subsection{Urban Fringe Settlement and its Impact}

Informal settlement (also referred to as a shanty town or squatter settlement) has been defined in various ways depending on the planning and legal framework of a country where it exists. They are characterized mostly by the low quality houses and the lack of, or inadequate infrastructure and social services. Informal Settlement (IS) has been perceived both as a problem and solution to housing needs in speedily growing cities of many developing countries (Srivinas 2005, Todaro 1994 cited in Mohammed and Suleiman (2006)). Informal settlements in accordance to this study refer to an illegal squatting around the border area. There are a number of effects surface out due to the prevalence of informal settlement. According to Mohammed and Suleiman (2006) the sprawling of poorly controlled settlement developments has resulted in many environmental and health related problems. Uncontrolled settlement development is causing physical disorder, uneconomical land utilization, and excessive encroachment of settlements into good agricultural land, environmental degradation and pollution risks (COLE, 1995 cited in Mohammed and Suleiman (2006)). Also, as explained below, it has become very difficult for the government to send social and economic infrastructure/services to these areas due to the lack of space and accessibility.

The most common consequences of the expanding informal settlement include pollution of water sources, deforestation, pollution from solid and liquid waste, flooding encroachment of good agricultural land, lack of many social services, and infrastructure.

\subsection{Summary}

On the past three decades prior two late 20th century uncontrolled Urban growth particularly towards periphery is seen a measurement to great-full and prosperity of a town all over the world. Because of different problems humbling on the environment and agricultural lands, determining urban boundary, however, comes as a very decidable issue. So, the proponents of urban sprawl theory faced challenges by advocates of UGB theorists. As a result of their reasoning rationality the second theorists or advocates of UGB comes most popular and in turn enjoying acceptances in the very recent times especially by the environmentalists. Though it has some disadvantages, many scholars assured that determining urban boundary is more worth for a city in 
many dimensions than letting its uncontrolled sprawl growth. There for Dealing with this issue on the case of Ethiopia is more worth too.

\section{Research Methodology}

\subsection{Introduction}

Actually, this chapter incorporates the type of methodologies which was used in the investigation. It includes seven different sections which are preceded by the operational definitions of variables. Section Two includes research design / research approach/ followed by the rest five sequentially. Which are research method (research techniques), Sources of data, sampling design (population or universe, sampling frame, sampling unit, sampling techniques and sample size), data analysis and interpretation, data presentation and limitation of the research?

\subsection{Operational Definition of Variables}

The reliability and validity of the data depends on the sex, age, and educational background. As well as residence duration in the study area, occupation, and income level of the respondents. These variables can have either Positive or negative influences on the data which are going to be gathered. Hence, this has used as variables in this research work. For example, educated people are more capable of explaining the role of GI in the development of the town than those who are illiterate; Moreover, people who have good jobs can have good income and then would have an opportunities to plan having a decent and resilience house, so that, can express more. In addition, respondents who have lived very long years in the study area could explain well about what was, going on, and will happen on their cities about the condition of boundary than those they have lived very few. The operational definitions of variables about Determination of Urban boundary and its impact for the purpose of this study have provided as follow:

Urban- with regard to urban, there is no uniform definition among scholars. Nations define urban centre based on their criteria. Most countries give a considerable weight for population size as a parameter while other consider a centre of settlement that relies heavily on manufacturing and service sector (non agricultural employment) and compactness and density (satterth Waite and Tacoli 2003, n.d. cited in Isaac (2009)). Urban, however, is an area or entity where 2000 and more people live and its economic activity is totally determined as non-agricultural.

Urban-, according to (the draft of boundary demarcation model directive (2012, Amharic Version), refers to an area where municipality or Town Administration is a structured that contains 2000 and above population size among which $50 \%$ is occupied on non-agricultural activity.

Boundary-is the notion of limits, lines or boarders (Avis, et.al., 1983 cited in Registered nurses Association of Nova Scotia, 2002).

Urban Boundary-Is, in combination of the above terms together, a line [could be imaginary, manmade or natural] which used to differentiate or divide an area called urban with other area (could be urban or nonurban). In this case a line demarcates Shire Inda Silase with its neighbouring or surrounding agricultural land, barren land or a Residential place which is dedicatedly determined by law as they are under the rural administration.

Urban [Municipal] Administrative Boundary-Is an area that falls under a recognized jurisdiction, such as a magisterial district or a municipality. It is bounded by a legally defined line (South Africa Census, 2001). It also refers to the border which indicates an administrative area of one town as well as differentiates it from the neighbouring locality, kebele, or other town or rural administrations.

Land Administration: the term Land Administration no one agreed definition among the organizations and or countries. For instance: (Stig, 2009) defined it as "the processes of determining, recording and disseminating information about the tenure, value and use of land when implementing land management policies." Again, Land administration is "the regulatory framework, institutional arrangements, systems and processes that encompass the determination, allocation, administration and information concerning land. It includes the determination and conditions of approved uses of land, the adjudication of rights and their registration via titling, the recording of land transaction, and the estimation of value and taxes based on land and property. There are three components of land administration: land rights registration and management; land use allocation and management; and land valuation and taxation (Ian, 2001). Whatever it defined in many ways as many agrees [and a more related to this context is] that a good Land administration system which guarantees security of tenure; provide security for credit; develop land markets; environmental protect state/communal management; etc. lands; Furthermore, reduce it is land asserted disputes; that support sustainable development cannot be attained in the absence of a functioning land administration.

Determining urban boundary- is the process of making or placing demarcation in between the urban entity and rural entity In case of this investigation, it is the process of putting clear cut demarcation among Shire Inda Silase and its Surrounding area.

Out coming Impact- refers to the coming soon result or the coming impact (On line free dictionary, 2001). In this context, therefore, refers to the impact of putting demarcation in between two areas (could be between urban-urban, urban-rural or urban-surrounding agricultural, barren and other land type). In case of 
this research it indicates the result, or consequence of putting clear cut demarcation among Shire Inda Silase town and its surrounding Areas on the ULGA land administration of Shire Inda Silase.

'Wereda'-is an Amharic and/ or Tigrigna language refers to a kind of administrative structured by the federalism government system in suit of decentralization of power that have a population of 20 , 000 and above in Ethiopian context.

'Kebele' - is also the same to the above which refers to a kind of administrative structure given by the federalism government system in suit of decentralization of power that have small number of population next to wereda.

Mender'-is an administration tier which is part of the lowest local government administration next to Kebele. That is similar to a village.

\subsection{Research Design}

This research is both qualitative and quantitative research type, because it deals with the experience of the ULGA in determining urban boundary. In addition, as far as it deals with the assessment of boundary issues existed on the ground it uses a case study strategy by devoting a special focus on the areas which show the problem highly evolved. At last, as far as this investigation is conducted in this year only, it is a cross-sectional research type.

\subsection{Methods of Data Collection}

For primary Data: - the units of observation of the study are the households of Shire Inda silase town residents on the border area and the land department administrative unite of the ULGA of shire Inda silase. Therefore, specific samples are taken from:

1. The farmers and who live around the green area (an area which has competing interest). Because they are one of the affected groups

2. The informal residents who squat again at around the green area, because they are also affected by the conflict arise the computing interest of an area and by the process of demarcation

3. The administrative unit of land development and management or the so called "Ye Meriet Lmat Ye sira hidet" of the Shire Inda Silase town, because they can also faced with difficulty in administering the land around that green area perhaps especially the committee formulated to study and report the issue of settlement around the boundary area.

So the methods I used to collect data from these sections of my study population are:

- Closed Ended Questionnaires for the number of samples who can read and write;

- Structured and unstructured Interview for those who cannot read and write;

- Open ended questionnaires;

- Structured observation- around the town fringe, specially at the case study kebeles;

- Semi-Structured Interview.

For Secondary data:- I prepared documents specially made around the area of this study from different books, Internet journals, proclamations and directives, reports of the committee studied and submitted to the ULGA, and exploring any other relevant materials if available. I decided to use only this method, because I assume that this can enables me to exploit the necessary documents I need and also I am most familiar with it.

\subsection{Sample Design}

\subsubsection{Population or Universe}

A research population is generally should be a large collection of individuals or objects that is the main focus of a scientific query. It is for the benefit of the population that researches are done. According to the (Central Stastics Agancy of Ethiopia Report, 2007) the total population of the town Shire Inda Silase is 52,782. However, due to the large size of the population of the study area, the researcher often cannot test every individual in the population because it is too expensive and time-consuming.

The studies Target population, thus, are taken from the two kebeles (called 03 and 04) of which competing interests is widely observed. I decided to take the sample only from the two kebeles because especially in these kebeles there are a repeatedly observed conflicts among the two wereda administrations caused by double ownership claim over the same parcel of land, there are a number of squatters and there have been several demolishing interventions on the border areas which are not known by whom it is administer. So, In order to solve this problem the samples were taken from these two kebeles as follows. 
Table-3.1. the number of samples sampled from the case study 'kebele' population, specifically from the selected menders and the population live on the edges of those 'kebeles'.

\begin{tabular}{|c|c|c|c|c|c|c|c|c|}
\hline \multirow[t]{2}{*}{ No. } & \multirow{2}{*}{$\begin{array}{l}\text { Name of } \\
\text { kebeles }\end{array}$} & \multirow{2}{*}{$\begin{array}{l}\text { Settlement } \\
\text { areas } \\
\text { (Menders) }\end{array}$} & \multicolumn{3}{|c|}{ Total population } & \multicolumn{2}{|c|}{ Sample size, $n=N^{*} 15 \%$} & \multirow{2}{*}{$\begin{array}{l}\text { Types of } \\
\text { sampling }\end{array}$} \\
\hline & & & Male & Female & Total & $\begin{array}{c}\text { Total sampled } \\
\text { households }\end{array}$ & $\%$ & \\
\hline \multirow[t]{2}{*}{1} & Hibret & 1.1 May-umut & 55 & 63 & 118 & 17.7 & $14.75 \%$ & \multirow{5}{*}{$\begin{array}{l}\text { Simple } \\
\text { random } \\
\text { sampling }\end{array}$} \\
\hline & & $\begin{array}{ll}1.2 & \text { Wekar- } \\
\text { duba } & \end{array}$ & 94 & 51 & 145 & 21.75 & $18.13 \%$ & \\
\hline \multirow[t]{2}{*}{2} & $\begin{array}{c}\text { Adi- } \\
\text { Kentibay }\end{array}$ & 2.1 Adi-ademay & 164 & 136 & 300 & 45 & $37.50 \%$ & \\
\hline & & 2.2 Adi-Dakano & 130 & 107 & 237 & 35.55 & $29.63 \%$ & \\
\hline Total & 2 & 4 & 447 & 357 & 800 & 120 & $100.00 \%$ & \\
\hline
\end{tabular}

Source: Field Survey, 2013.

In addition to this the 21 number of respondents taken from the Municipal administration officials and the 10 other officials taken from Tigray Urban regional Planning office called 'kilil Bureau of Tigray', and from the Shire Inda silase Urban Planning and consultancy offices as well as from the Shire Inda Silase's administration office were taken through purposively.

\begin{tabular}{|c|c|c|c|}
\hline R. No. & Population & Sample size & Sampling technique \\
\hline 1 & $\begin{array}{l}\text { From the 'Tigray' urban planning and consultation } \\
\text { regional office called "Kilil Bureau" }\end{array}$ & 2 & $\begin{array}{l}\text { Purposive } \\
\text { technique }\end{array}$ \\
\hline 2 & $\begin{array}{l}\text { From the Shire nda Silase's urban planning \& } \\
\text { consultation office }\end{array}$ & 6 & \\
\hline 3 & $\begin{array}{l}\text { From the Shire Inda Silase's Mayor's administration } \\
\text { office (both the former and the present Mayors) }\end{array}$ & 2 & \\
\hline \multicolumn{2}{|l|}{ Total } & 10 & \\
\hline
\end{tabular}

\subsubsection{Sampling Frame}

As far as study of the whole population (households) of Shire Enda Silase or even the total population of the case study kebeles is too Difficult and Time consuming The Sampling is framed only towards the number of households live at the contested are of the two kebeles (Kebele 03 and 04) which have more critical problems. Then the total population from these contested areas of these kebeles is 800 households of. Therefore, listing of all these households is too difficult.

\subsubsection{Sampling Unit:}

The unite of analysis or sapling unite of this investigation are households of the two kebeles specially those who squat informally around the periphery and which can affected by the boundary demarcation, the rural households live near by the town.

\subsubsection{Sample Size [determination]:}

According to Kothari (2004) to select the sample size it should be optimum size, and it could be neither large nor too small. The study population target is infinitive the formula was used as follows, and then the case of homogeneity, availability of the finance and to be effective and manageable sample size the confidence statistical significance was employed as follow. That is: If $\mathrm{N}>10,000$ and If $\mathrm{N}<10,000$ (Kothari, 2004). Therefore, the total population of the study is $\mathbf{8 0 0}$ so it is below 10,000. Even it is below 1000 so In order to get proportional sample size of the house hold I use the Rule of thumb formula. This is: 
$\mathrm{n}=\mathrm{N} \times \mathbf{1 5} \%$ Where,

$\mathrm{N}=$ total population

$\mathrm{n}=$ Sample size

$15 \%$-=given by rule of thumb (10-30)

Given: $\mathrm{N}=80015 \%=0.15$
According to the above formula: Given: $\mathrm{N}=800$ 15\%=0.15

$n=N \times 15 \%$ then $n=800 \times 0.15$

$\mathrm{n}=\mathbf{1 2 0}$

Beside this 21 workers of the municipality were taken through purposive sampling. Then the total sample size would be 120 (from probability sampling) +31 (from non-probability Sampling) $=151$

\subsection{Sources of Data}

Both primary and secondary data are used to undertake this research. This is because both types of data are needed to efficiently and effectively measure, analyze and judge the out coming impact of determining urban boundary on land administration.

\subsubsection{Primary Data Sources}

Primary data is obtained from primary sources (from sampled households and workers of ULGAs of Shire Inda Silase) by administering survey methods like interviews, questionnaires and observation

\subsubsection{Secondary Data Sources}

Secondary data are collected from different books related to urban boundary and boundary demarcation, international journals, different related proclamations and directives, reports and study results of the committee, etc.

\subsection{Data Analysis and Interpretations}

After collecting data through the above instruments, it was important to organize, present and analyze in a systematic way. Based on this, both quantitative and qualitative methods of data analysis were used to describe the issues. The quantitative includes frequency, percentage, tables, graphs and charts to manage, examine and analyze. Finally, the consequent reports were deployed through Excel program by the researcher.

\subsection{Data Presentation Instruments}

Data collected of this investigation was summarized by numbers, percentages, photographs and maps and the suitable data presentation tools of this study were tables, pie charts, photographs, bar graphs and Thematic maps. The qualitative data was simply discussed and analyzed qualitatively in a way it presents the information appropriately.

\subsection{Ethical Considerations}

Before starting collection of data through questionnaire distribution and interview, the researcher, tends to have official permission from the concerned body. Because of that the researcher got an official permission letter from Ethiopian Civil Service University institution of urban studies; department of urban land development and management. The respondents of the questionnaire and the key informants were also told about the purpose and objective of the study at all. Or the researcher makes clear about the use of the investigation for the research participants before they pretend to respond or give information about what they were asked. The researcher was also much high attention towards keeping the right of the informants. Or the researcher tends not to cross the line of respecting of the research participants right and dignity.

\subsection{Limitations}

Difficulties had occurred to get organized and well developed time series and evident data on the issues. Moreover, officials giving lengthy appointment for interview, some household respondents did not give appropriate responses to some question items due to different reasons were the major obstacles occurred while conducting the study. In addition to this the limited knowledge or confused understanding about the boundary types, such as among administrative boundary and planning boundary pretended to limit the quality of responses supposed to be gathered. Although it was difficult to avoid the consequences of such problems on 
the accuracy of the study, by maximizing the efforts it was able to minimize and get as current analysis as possible.

\subsection{Summary}

This investigation had run through both quantitative and qualitative type. This is because it collaborate both empirical and non-empirical data. It was focused on explaining the existed condition of boundary and related problems happened in the study town more specifically in the case study area. So, the researcher's investigation follows explanatory research type as the same time case study research strategy. The investigation totally depletes a one time or non-continuous study time, so that it was a cross sectional research type. The researcher uses both purposive and non-purposive or probability (simple random sampling) sample taking techniques. Using these methods the researcher took 120 households, 21 workers of land development and management department of Shire Inda Silase, and 10 officials from different offices in which the researcher considers as they are more relevant. The researcher also use questionnaires, intensive interviews, and archival and report reviews to collect data from both primary and secondary data sources. At last the researcher would plan to present and discussed the data through tables, graphs, charts and thematic maps and triangulation mechanisms respectively.

\section{Finding, Analysis and Interpretation}

\subsection{Introduction}

This chapter discusses the results or findings from both the primary and secondary data that had been collected and analyzed in the course of study. It has been summarized the data findings in relation to the response rate, demographic data and elaborated representation of the findings. When we look to the case response rate, in the primary data collection, 141 questionnaires which are two types were distributed for respondents. The respondents include from two different unite of analysis. These are: One, households living at the boundary adjacent of the two Kebeles (03 and 04) of Shire Inda Silassie town, in which 120 questionnaires provided to be responded. From these questionnaires; 110 of them are filled correctly and returned, 3 of them are incorrectly filled and returned, 7 of them are completely abandoned filling, tear and damaged to the extent of unable to read the writings. Totally 110 are responded correctly and the remained 10 questionnaires are incorrectly responded. Second, the workers of the ULGA land department units counted 21. These samples were correctly answered and returned all of them. Of these 141 questionnaires 131 are got a response. The response rate is, therefore, $92.91 \%$. In Addition, a structured interview was undertaken with 10 officials from the Tigray Urban Planning Office and from the Shire Inda Silase Urban Planning and consultancy offices.

\subsection{Context of Study Area}

Shire Inda Silase town, as described in chapter one, is found in the north-western zone of Tigray region. Shire is one of the most economic corridor zones of Tigray. The study area is surrounded by small an economic area found in the administrative jurisdiction of the rural wereda and that have economic contribution to the city. These are: 'Shire Inda Silase betekirstian'-0.s km, Wekar-duba-2 km, Adi Dacano-2 km, AdiAdemay-4 km, Amba Georgis-4 km, Adi Gidad-5 km, Adi Chemo-6 km, Adi nekizen-6 km, Adi Gedena-6 km, Mai Scebenni-6 km, Adi Keray- 7 km, etc (Google Satellite, Monday 25/02/2013). The distance of which these areas were measured is from the centre. The surrounding 'kebeles' of the rural 'wereda' integrating with its wide accesses to transport and other social services like education, electricity, water and telecommunication made Shire the most important area in the region and the zone. Shire had bordered by these economic areas. These are mainly areas of the one 'kebele' of the surrounding rural 'wereda' or 'kebele' of "wereda Tahitay koraro" called "Tabla Lemlem". See the following figure. Those areas, as they are shown on the Figure 4.1, are plain areas and this condition made them easily attracted through expansions. As a result the town without a limitation is expanding horizontally. 


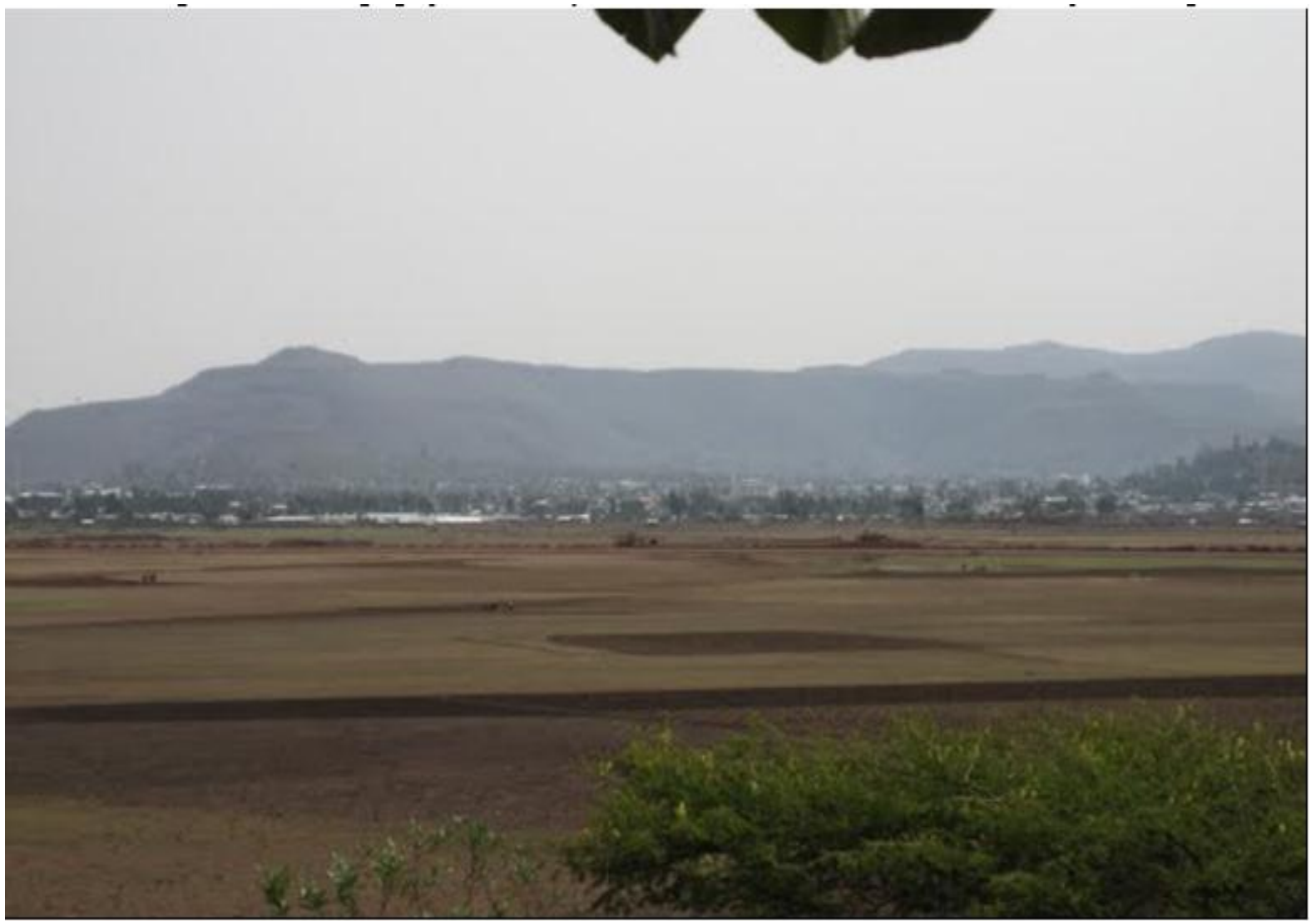

Figure-4.1. Shows the geographic suitability of Shire Inda SIlase town for the horizontal expansion or growth. Source: Survey Study, 2013

This aerial photo is need to show how the town is surrounded with the agricultural potential lands and the suitability of the surrounding area for easy possibility to grow horizontally and in turn could reveal conflicts on among the two 'wereda' administration

According to the Shire Inda Silase Situational Analysis report (2006), the Shire Endaselassie Municipal Services Management team highlighted 14 items with regard to information, systems and processes, and employee capacities that limit the ability to carry out their responsibilities as defined by their position descriptions and the organization structure. By far, the greatest challenge facing Shire's organization is the deficiencies found in the human resources of the city as articulated below.

Information: In general, Shire Endaselassie's main information problem is the outdated information base, both in terms of currency and method of storage. This translates into second level information generating issues as described below.

- Lack of understanding what is relevant data used for analysis;

- Manual recording of all data does not allow for decisions to be based on current data especially as it relates to projecting expenditures;

- Inability to collect information on newest trends and practices;

- $\quad$ Lack of data to determine accurate service charges; (Deborah \& Tadesse, 2006)

- Systems and Process: According to Shire Inda Silase Situational analysis report prepared by Deborah and Tadesse (2006) Shire Endaselassie's ability to process and analyze information is severely limited by its lack of information technology, both hardware and software, and communication equipment. The following illustrates immediate areas of concern.

- Shire performs all analysis manually, including data entry and data manipulation;

- Inability to produce current accounts due to manual recording of financial data requires a methodology for analyzing service delivery fees;

- Staff communications are not efficient due to lack good integration system among the workers;

So having such like deficiencies can aggravate more to the issue of having a loosely demarcated boundary. It also puts a favourable condition for not having clear information about the condition of households live at the town periphery. That is the reason for why the researcher found this investigation so important and reacts with dealing it. 


\subsection{Demographic Data}

This part indicates the Socio-economic condition of respondents. This means about the age, sex, marital status, and economic condition of the respondents. The respondents of this study were households sampled from the residents of the town which lives at the urban fringes and the workers of the Shire Enda Silase ULGAs office. The researcher describes about the socio-economic condition of the household respondents only. This is in assuming that explaining about the socio-economic condition of employees of ULGA is not much necessary as far as they are experts the information they give may have professional judgements. So the description of respondents had determined to the households respondents.

\subsubsection{Demographic Data of Household Respondents}

This section describes about the age, sex, marital status, educational level, occupation, income level, and the time span in which the h.ousehold heads sampled from the study area.

\section{A. Age, Sex, Marital Status, and Occupation}

Based on the responses collected from respondents, 60.4 per cent were males whereas the remaining were females (i.e. 39.6\%). This indicates that the study is constituted from both sex categories, so that it is representative. In addition to this, so as to make it more evident the study includes 15 and above age groups as shown in the following table. The reason that the researcher needs to include this wide age group is, in order to have wide participants for the study. Furthermore, regarding to the marital status of the respondents the highest category is the married groups. These groups are assumed as more egger to have their own houses as far as they have high probability of get birth and in turn make a large size family. As we know a large size family or a couple which have high tendency to make a family in near times always tend more to have a house. That's why the researcher focused on the married groups. Finally, as which is indicated in the preceded table Table 4.1, the job status of the respondents that accounted for 65.6 per cent are employees of different sectors such as private, governmental organizations, NGOs and other sectors. For more understanding see Table 4.1 below.

Table-4.1. Shows the Age group, Marital Status and Job Category of the respondents' sampled from the households of the study area.

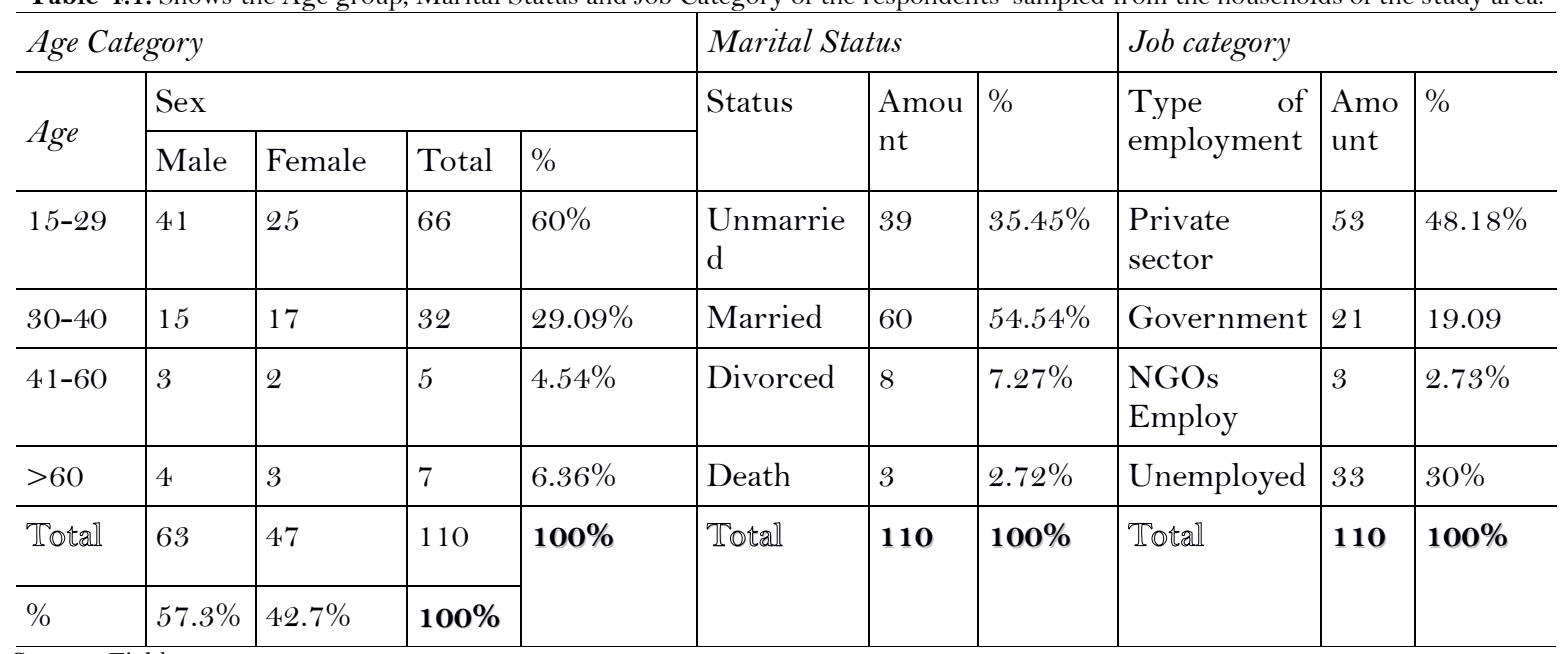

Source: Field survey, 2013

\section{B. Educational level of Respondents}

This part induces about the educational level of respondents and the corresponding knowledge they have about describing and explaining the issue of boundary and its effect on the study area as well as on the works of the land administration department. According to this fact the educational level of the workers of the Shire Inda Silase land administration office or the municipality is presented as follows. See Figure 4.2 below. 


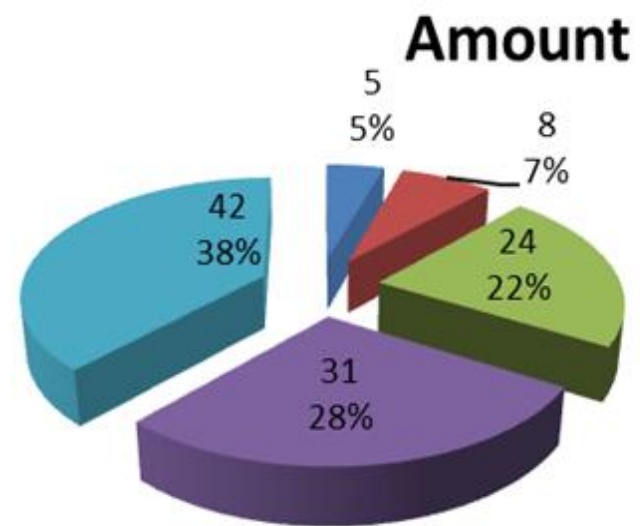

No formal education

1-4 Grades

5-8 Grades

9-12 Grades

Diploma and above

Figure-4.2. Educational levels of respondents.

Source: Field survey, 2013.

The above Figure 4.2 Expresses that though the largest share of the respondents were the educational groups of diploma and above followed by grade 9-12, then followed by 5-8 grades; the study was also concerned from grade one and above educational groups, therefore, it is reasonable that more educated people can justify the existed condition about the boundary demarcation issues and its impact on the town of Shire Inda Silase.

\section{The Duration of Stay in the Study Area}

Table-4.2. Respondents by years of life span in the Woreda (Kebele).

\begin{tabular}{l|l|l}
\hline Life span in the 'woreda (Kebele)' of the research area & Frequency & Percentage \\
\hline Below 5 years & 36 & $32.73 \%$ \\
\hline 6-10 years & 39 & $35.45 \%$ \\
\hline $10-15$ years & 17 & $15.454 \%$ \\
\hline $15-20$ years & 11 & $10 \%$ \\
\hline Above 20 years & 7 & $6.364 \%$ \\
\hline Total & $\mathbf{1 1 0}$ & $\mathbf{1 0 0} \%$ \\
\hline Source: Researcher's Field survey, 2013. & &
\end{tabular}

As it is indicated in Table 4.2, 32.73 per cent and 35.45 per cent of the respondents were from the residents who lived for 5-10 years and above 11-20 years respectively and these groups are because of less years lived in the town made them to live or have the house at the edge or fringe of the town perhaps specially in the case study area; thus they can have high probably to describe about the situation happen in that specific area. However, living relatively a long time in the study town helps people to have more chance to hold a house in the urban centres and because of that they can understand little about the situations happen at the urban infringes.

\section{The Income Distribution of Household Respondents}

Here, the researcher describes about the income distribution of respondents sampled from the area near to the edges of the town (see the following figure). 

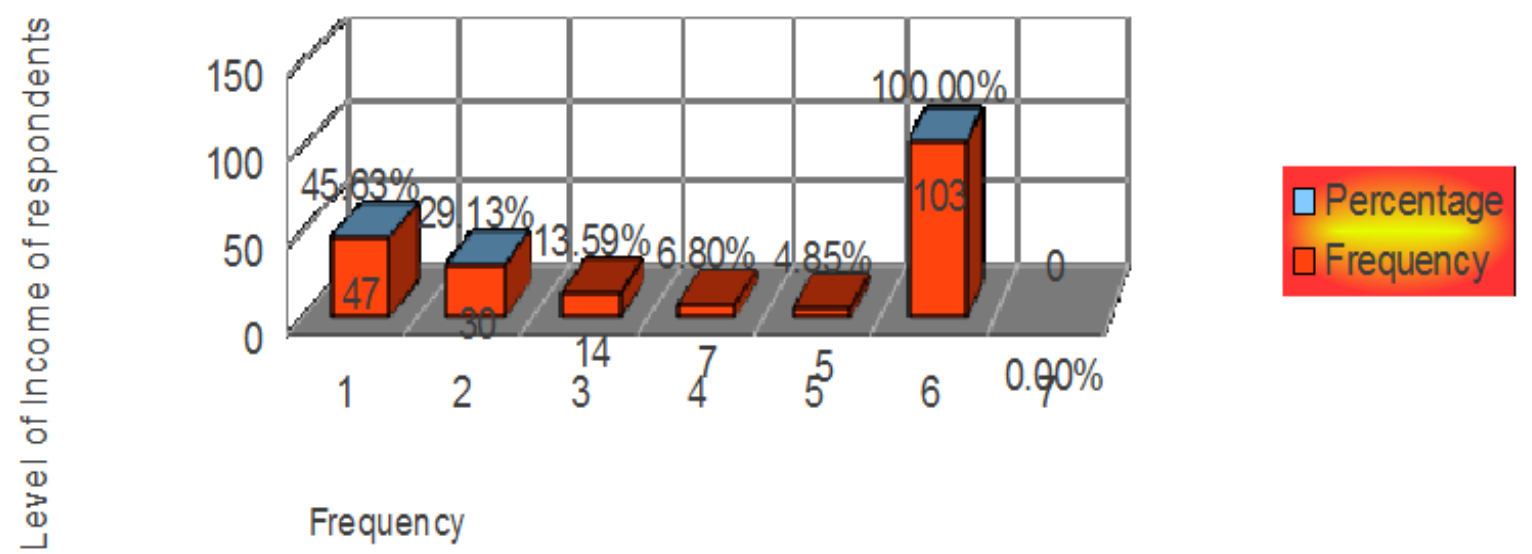

Figure-4.3. The income distribution of household heads sampled from the case study area of Shire India. Source: Field Study.

The data in Figure 4.3 describe that $45.64 \%$ of the sample house hold heads, regarding to the cost of houses of this day, are of acquiring ranging from monthly income of ETB below 1500 USD (\$) of below 83, $29.09 \%$ of the sample house hold heads are middle earning a monthly income that ranges between ETB 1501300 or USD (\$) 84-166 per month. Second, those who earn a monthly income that ranges from ETB 30014500. Of the sample house hold heads, the reset those who obtain ETB 4501 and above or USD ranges from 167-250 per month. Therefore, the first two groups of households have a probability to live and have a house at the town fringe, so that they can explain well about the prevailing condition of boundary and its scenarios. From the above data, the researcher by starting from the above figure the higher number of the respondents was categorized in the low income category. People those who have low income achievers are could force to hold a house or a living at the low cost area such as the urban infringes.

\subsection{Results or Findings}

This section will describe the presentation of data collected from and organized through different presentation mechanisms. It also includes the interpretation and discussion made by the researcher on the data collected, organized, and presented through different mechanisms. The researcher put presentation of data collaborates with his interpretation and discussion. This is in assuming of making clear and coherent idea about the investigation.

\subsubsection{The Existed Condition of Boundary of the Town}

This describes data of the existing condition of boundary in the selected Kebeles of Shire Inda Silase Town in reference to the primary and secondary data focuses on the knowledge of respondents about the boundary in the study area, conflicts happen around the loosely demarcated area, factors affecting the processes of boundary demarcation to be delayed, the opinion of the households and the workers of the Shire Inda Silase's ULGAs of land management and development unit, the impact of loosely demarcated or absence of boundary in the investigation area and Major Challenges find in the study.

\section{A. Knowledge of Respondents about the Absence of Boundary and its Due Effect on Shire Inda Silase}

According to the responses of both the sample of households and the workers of the land development and management office, for one town suppose like Shire, having a well known, distinguishable fixed boundary totally have many importance. Such as: having smooth and peaceful relationship with its neighbouring area, Control the effect of sprawl versus the environment, create an initiation for beatification and compact development in the centre, helps for the municipality workers of the town to better ground to know which area and whom household should be administrated in its jurisdiction, etc. To conclude it helps for the workers of the municipality in saving the town from all scenarios happen due to absence of boundary. However, according to the respondents, Shire Inda Silase, though there are some efforts recently started, it didn't have demarcated its boundary yet.

Table-4.3. the respondents' knowledge about the existed boundary of Shire Inda Silase.

\begin{tabular}{l|l|l|l}
\hline R.NO. & The degree of knowledge of respondents on boundary & Frequency & Percentage \\
\hline 1 & $\begin{array}{l}\text { Those who had been informed or hear before or Know about } \\
\text { boundary demarcation issues }\end{array}$ & 124 & $94.66 \%$ \\
\hline 2 & Those who have no knowledge about boundary & 7 & $5.34 \%$ \\
\hline \multicolumn{2}{l}{ Total } \\
\hline
\end{tabular}


As it is indicated from Table 4.3 above, of the total respondents which are 131 excluding the incorrect filled, spoiled, and unreturned and responded well (10 from the 141, see response rate), 124 which is $94.66 \%$ knows and they heard about boundary before, where as 7 or $5.34 \%$ of the actual respondents neatly or hardly know about boundary cases of their town.

-So, from this data the researcher can generalize that the responses which respondents bear about boundary and as well as issues around it could be totally true.

\section{B. The Current Figure about the Boundary Condition}

As we can see from Table 4.6 below, $89(71.77 \%)$ of the total actual respondents Three fourth were respond as Shire Inda Silase doesn't have boundary until recent time; whereas the remaining 35 (28.23\%) answered that Shire Inda Silase doesn't have well distinguished boundary. See Table 4.6 below.

\begin{tabular}{|c|c|c|c|c|c|c|c|}
\hline \multirow[t]{2}{*}{$\begin{array}{l}\text { R. } \\
\text { No. }\end{array}$} & \multirow{2}{*}{$\begin{array}{l}\text { The perception of } \\
\text { respondents about the } \\
\text { current boundary condition }\end{array}$} & \multicolumn{2}{|c|}{$\begin{array}{ll}\text { Shire } & \text { has } \\
\text { boundary } & \end{array}$} & \multicolumn{2}{|c|}{$\begin{array}{l}\text { Shire didn't have } \\
\text { boundary }\end{array}$} & \multicolumn{2}{|l|}{ Total } \\
\hline & & $\begin{array}{l}\text { Freque } \\
\text { ncy }\end{array}$ & $\begin{array}{l}\text { Percent } \\
\text { age }\end{array}$ & $\begin{array}{l}\text { Freque } \\
\text { ncy }\end{array}$ & $\begin{array}{l}\text { Percent } \\
\text { age }\end{array}$ & $\begin{array}{l}\text { Frequ } \\
\text { ency }\end{array}$ & $\begin{array}{l}\text { Percenta } \\
\text { ge }\end{array}$ \\
\hline 1 & Workers of Municipality & 8 & $38.1 \%$ & 13 & $61.9 \%$ & 21 & $100 \%$ \\
\hline 2 & Sample of Household heads & 27 & $21.21 \%$ & 76 & $73.79 \%$ & 103 & $100 \%$ \\
\hline \multicolumn{2}{|c|}{ Total } & 35 & 28.23 & 89 & $71.73 \%$ & 124 & $100 \%$ \\
\hline
\end{tabular}

Source: Field Survey, 2013.

From the above table, out of the total sampled household heads, $73.79 \%$ answered that Shire doesn't have boundary. Similarly, large number $(61.9 \%)$ of respondents from workers of ULGA of Shire Inda Silase also assures that Shire doesn't have boundary. On the contemporary, 38.1\% and $21.21 \%$ of the respondents from sampled household heads and workers of the Shire Inda Silase municipal office respectively answered as it have boundary. From this data the researcher can understand that the majority of household respondents and UlGA employee can share that there is no fixed demarcated boundary that separates Shire from the neighbouring wereda W/ro Nigisti Asmerom, head of Tigray Bureau of planning and consultancy, address that all towns and cities of Tigray didn't demarcate their boundary till recent time (interview made on 10 March 2013). According to W/ro Nigisti Asmerom, the only process they pretend to go is studying the problems and the consequences happen due to lack of boundary, setting directives, etc.

The researcher from his observation (made on March 26 \& 27, 2013) observes that there were informal settlements results because of absence of well defined and or fixed boundary at the urban fringe areas (see the following pictures taken from by the researcher during field survey).
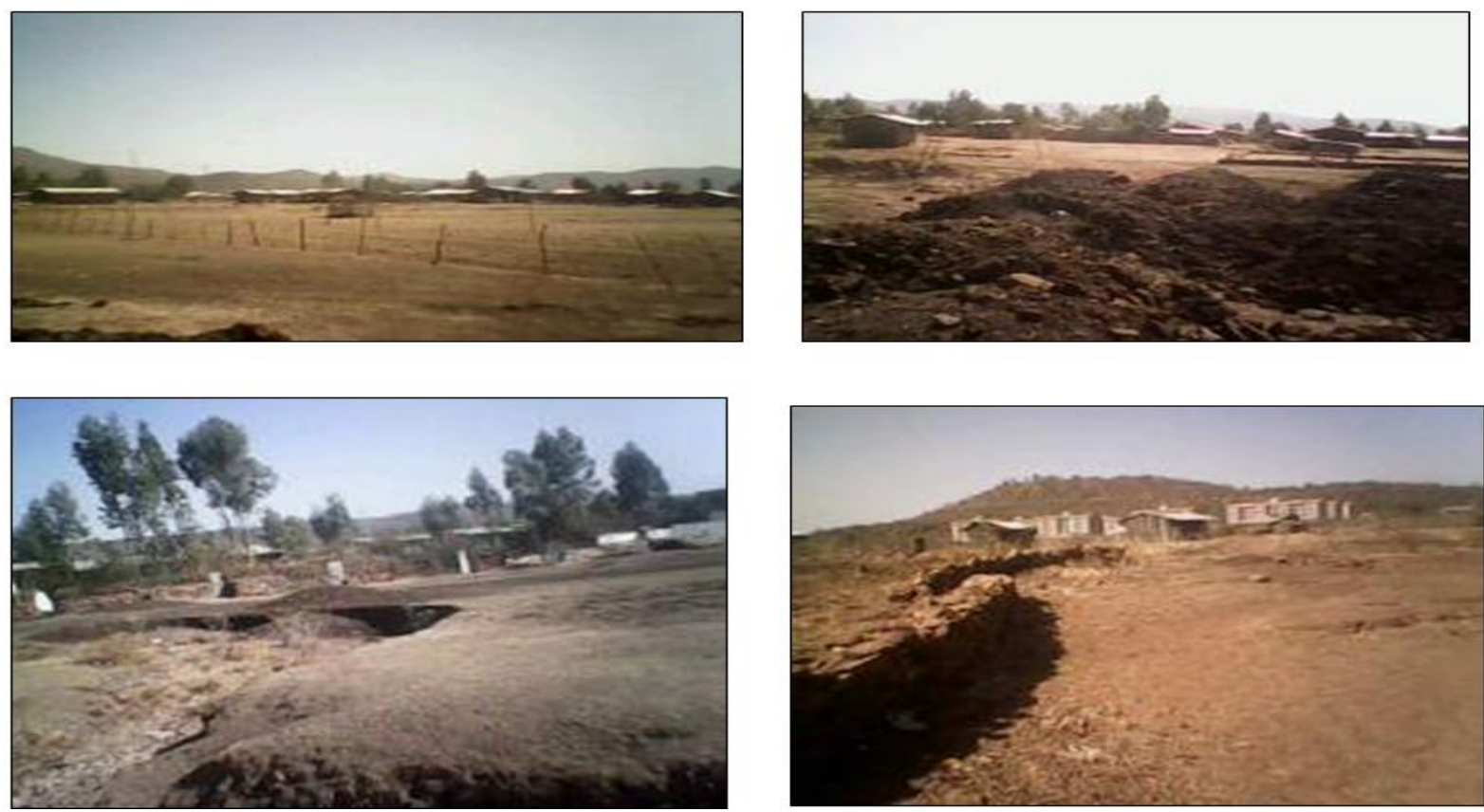

Figure-4.4. shows the informal settlements found in both case study area kebeles.

Source: Field survey, 2013. 
The researcher, with the photos presented in page 39 is needed to show that there were informal settlements around the town fringe of both kebeles which were result through absence of having demarcated boundary.

Ato Solomon, Planner and workers of land department of Shire Inda Silase explained that "as far as we revise its Master plan since2011, Shire Inda Silase has demarcated boundary" (Personal communication, 24 March 2013). However, According to the definition stated on chapter of this study planning Boundary doesn't mean municipal boundary.

Moreover, the researcher from the interview made with different concerned bodies (the mayor of the town, planners of the town, generally from all those who invited to interviewed) can had understand that there is a beginning to demarcated the boundary of the town. Such as: formulation of a committee which can study the problems happen around the town fringe, specially related to squatting and informal settlements, there is also starting of pinching pillars a bench marks based on the master plan revised on 2011. But those respondent who address that as there is boundary in the town because they misunderstands it some of them with the master plan and others with the processes started to make a demarcation in the current time.

-So, from the responses of the respondents (from the questionnaires, interview) and from his observations as described above, the researcher can confidentially talk that Shire, even though there are some beginnings such as recruiting a committee to study the problems raise through lack of having boundary, it didn't goes a real track to the extent of ending the problems from their sources for once and for ever yet. Therefore it is difficult to say that Shire Inda Silase had demarcated its boundary which can separate it from the neighbouring surrounding. From the responses of the respondents we can understand that Shire didn't demarcate its administrative jurisdiction and in turn distinguish areas found within its jurisdiction yet.

\subsubsection{Perspective of Sampled Household Respondents and Experts or Officials on the Necessity of Boundary Demarcation on Shire Inda Silase Town}

This section indicates the perspective or outlook of respondents from both those sampled from households live at the case study area, perhaps specially at the town fringe as well as perspective of respondents from the workers of the Shire Inda Silase municipal office. This helps to identify whether or not there is better possibility which prevailed on the ground for running smooth boundary demarcation process (see the following figure).
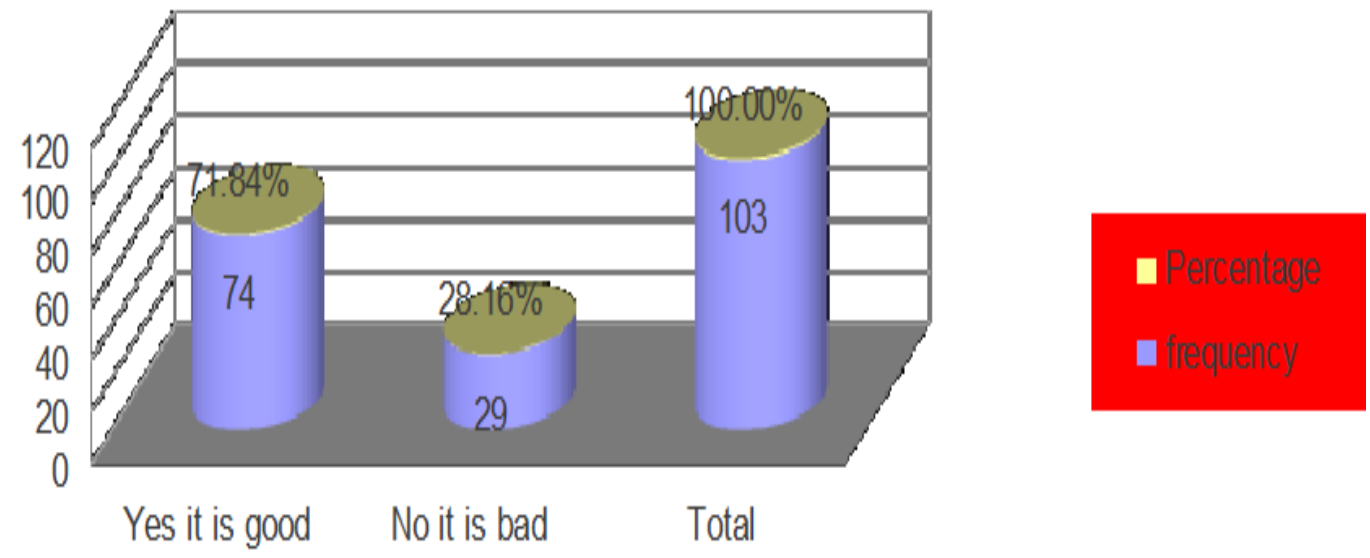

Figure-4.5. Respondents (of housholds) perspective on boundary demarcation. Source: Researcher's Field Survey, 2013.

From the above Figure 4.5 we can conclude the fact that $74(71.84 \%)$ of the house respondents described as they are willing enough to offer or accept the issue of boundary demarcation. Whereas the remained, 29 $(28.16 \%)$ of the household respondents describe as they couldn't offer boundary demarcation processes. However, as far as the boundary demarcation processes positively offered by majority (more than three fourth) of the respondents', the researcher can understands that there is a good opportunity to conduct boundary demarcation processes on the town of Shre Inda Silase. That means the majority of the respondents were found at positively appreciating and favouring the boundary demarcation issue on the Shire Inda Silase town. ULGA employee respondents also showed as they are well favoured and dedicated towards boundary demarcation processes if it is planned to demarcate on Shire inda silase town. (See the following figure).

The researcher from the above two figures, therefore, can conclude that planning to demarcate the Shire Inda Silase town administrative boundary could bear positive outcome on the life of the households reside at the urban fringe and totally to the condition of the town.

In addition to this, those who accept and or appreciate boundary demarcation issues address reasons like it had much importance. Such as resolve peace and security in 


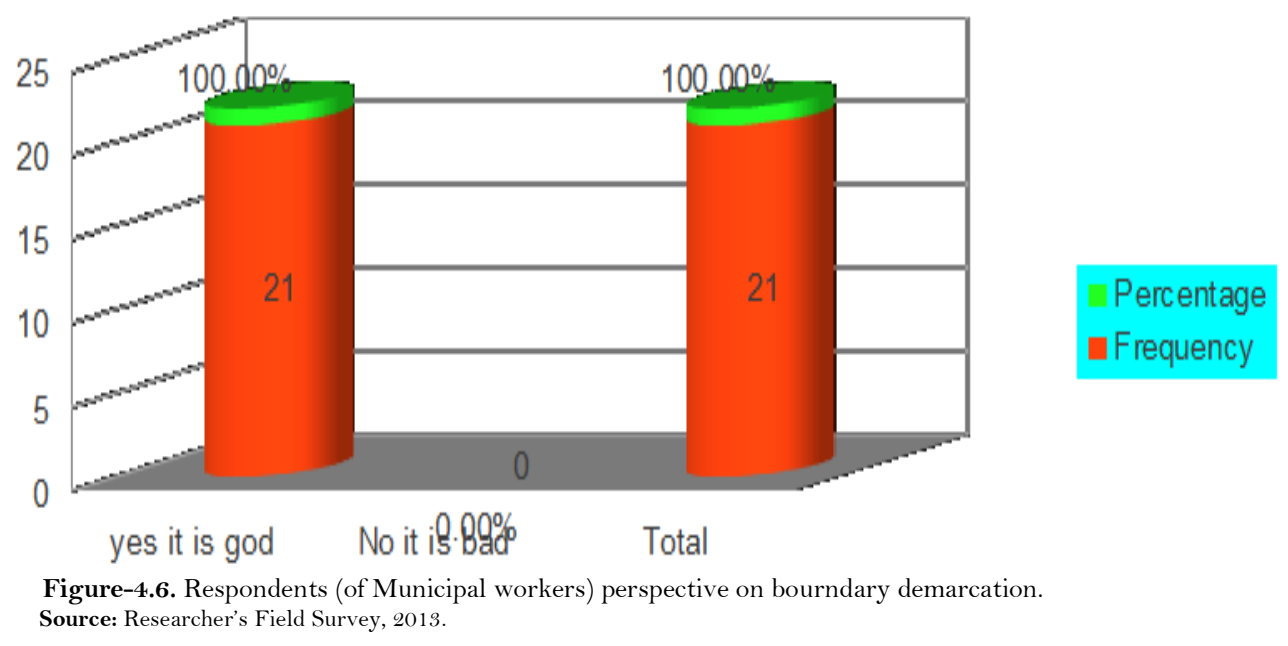

Between the two 'wereda' administrations, enable to avoid confusions for households on where they should get a service, etc. On the other hand, those who refuse to accept boundary issues perceived that if boundary is demarcated it hinder the development (like expanding or growing horizontally). (See the following table).

Table-4.5. The respondent's perceptions about the impact of boundary demarcation.

\begin{tabular}{|c|c|c|c|c|c|c|c|}
\hline \multirow[t]{2}{*}{$\begin{array}{l}\text { R. } \\
\text { No. }\end{array}$} & \multirow{2}{*}{$\begin{array}{l}\text { Degree of respondents } \\
\text { perception towards impact of } \\
\text { boundary demarcation issue }\end{array}$} & \multicolumn{2}{|c|}{$\begin{array}{l}\text { Absolutely Good } \\
\text { at all }\end{array}$} & \multicolumn{2}{|c|}{ Very Bad at all } & \multicolumn{2}{|l|}{ Total } \\
\hline & & $\begin{array}{l}\text { Freque } \\
\text { ncy }\end{array}$ & $\begin{array}{l}\text { Percenta } \\
\text { ge }\end{array}$ & $\begin{array}{l}\text { Frequen } \\
\text { cy }\end{array}$ & $\begin{array}{l}\text { Percenta } \\
\text { ge }\end{array}$ & $\begin{array}{l}\text { Frequen } \\
\text { cy }\end{array}$ & Percentage \\
\hline 1 & $\begin{array}{l}\text { Respondents sampled from } \\
\text { householders }\end{array}$ & 73 & $70.87 \%$ & 30 & $29.13 \%$ & 94 & $75.81 \%$ \\
\hline 2 & $\begin{array}{l}\text { Respondents from workers of } \\
\text { Shire Inda Silase municipal } \\
\text { office }\end{array}$ & 21 & $100 \%$ & 0 & $0.00 \%$ & 30 & $24.19 \%$ \\
\hline \multicolumn{2}{|c|}{ Total } & 94 & $75.81 \%$ & 30 & $24.19 \%$ & 124 & $100.00 \%$ \\
\hline
\end{tabular}

As indicated above on Table: 4.5, 70.87\% of the respondents of the sample of households perceive that cumulative effect of boundary demarcation absolutely good at all aspects of their life or benefits them in all rounds. As well as $100 \%$ of respondents from the workers of Shire Inda Silase municipal office perceive that Demarcating of boundary of Shire Inda Silase is good for the life of the households and their works related with it. Totally, $75.81 \%$ of respondents from all respondent parts adders perceive that boundary demarcation is good at all rounds. Whereas, the $24.19 \%$ of the respondents sampled from households perceive that it is bad at all aspect of their life and their living.

The researcher from the above data can understands that majority of the respondents perceive as demarcating boundary of Shire Inda Silase could totally have positive outcome on the life of themselves and the town. Therefore, the researcher, from the point of view of the respondents can reveal a conclusion that conducting boundary demarcation issue, on one hand, could not affect the life of the residence live at the town fringe, on the other hand may not faced with difficulty in the time of demarcation processes.

In addition to this the following figure also try to demonstrate about what looks like the perception of respondents on the degree of impact. 


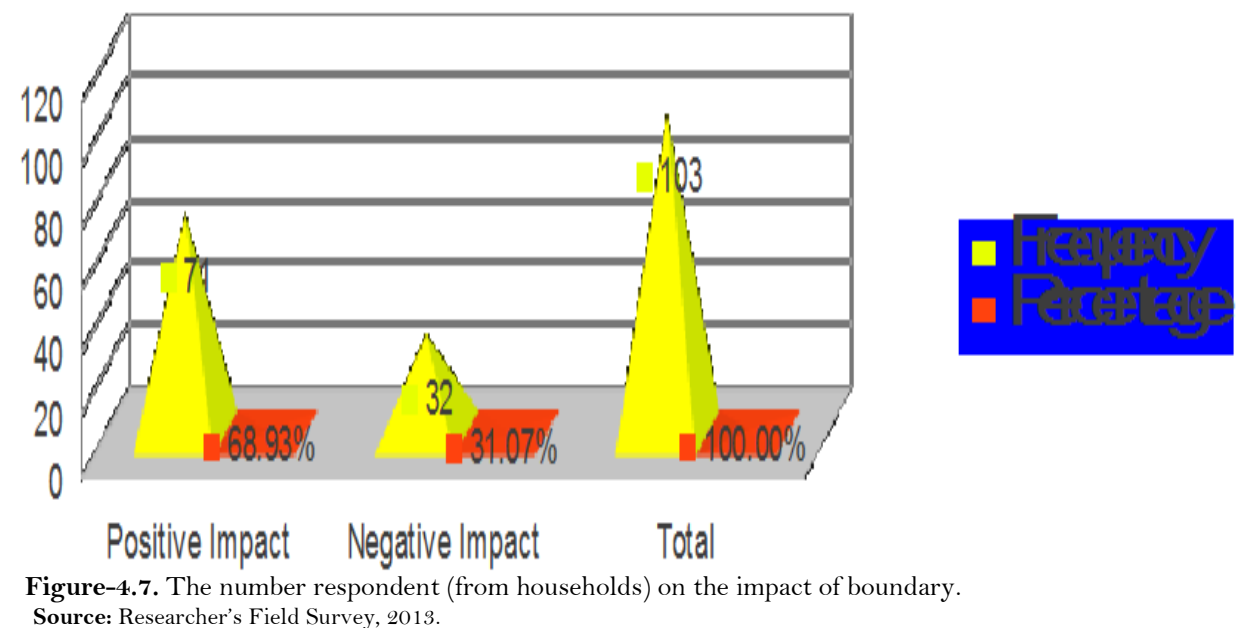

From the above data in Figure 4.7, 68.93\% of the respondents sampled from households, assure that boundary demarcation have positive impact to their life and the town; whereas the remained $31.07 \%$ responded as conducting demarcation of boundary could put negative impact on their life and the town.

On the other hand, the respondents which taken from the Shire Inda Silase Municipal office answered as conducting demarcation of boundary on Shire Inda Silase could totally bear positive impact on the life of the households live at the town fringe and in turn to their works as well as to the town. See the following data presented on Figure 4.8 below.

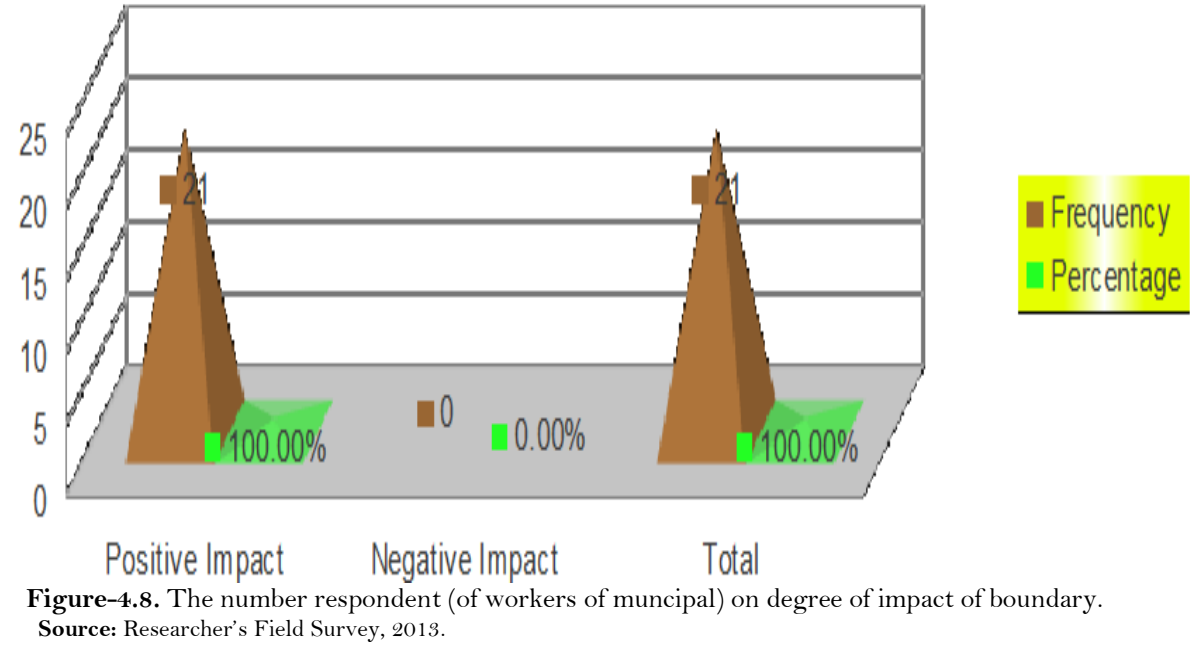

From the data in Figure 4.7 and Figure 4.8 (pp, 46), we can understand the fact that $70.97 \%$ of the total respondents (sampled household and the respondents from the workers of Shire Inda Silase municipal office) address that conducting boundary demarcation process in Shire Inda Silase town could bears positive impact. Whereas 29.03\% of the total respondents (from both section of respondents again) suggests as it is bad, as far as it bears negative impact they said. Therefore, from the objectives of this study and the important literatures reviewed on chapter two, the researcher conclude that having loosely demarcated boundary and/ or lack of well defined boundary could put different influences and totally contribute to a mess for the life of the households live on the town periphery and for Shre inda Silase town. For instance: (Pierre, 2003 Cited in Bhatta (2010)) in his journal article called Causes and Consequences of urban growth and sprawl, tried to show as to what extent that the antiquity of uncontrolled urban growth creates impact on climate (air pollution), high cost of development, deteriorating quality of life, environment, and perhaps specially on land administration of the town and in turn how smart growth can implement within the prevailing political, economic and value environment. According to Staley and Mildner (1999) having a boundary or demarcating boundary of one town or city has a multi many benefits (See Chapter one: Background of the study. Pp: 2).

-The above data organized from the responses of respondents (as we can see above from the above figures; Figure 4.7 \& Figure 4.8 respectively) also show that demarcation of one's boundary have a multi-faceted positive impact on the town or city. In addition to this, the above data also proofs that lack of having good urban demarcation puts a multi dimension problem on the livelihood of the residents who live in the town edge and also makes difficult the land and related management system for the workers of the municipality. 
Such as: facing difficulty like an able to administer the areas found within the municipal jurisdiction ; an able to distinguish exactly which household is a residence of a town and who is not; makes difficult the land registration and cadastre system; bears conflicts in between the urban and rural administration through double ownership claim etc. Therefore, the researcher by deducing from the responses offered by the respondents dedicatedly appreciates that there is a good laid or foundation to deal over the boundary demarcation processes. This is to mean that the households of Shire Inda Silase as well as the workers of Shire Inda Silase municipal office positively appreciated to Shire Inda Silase municipal office for the plan they have to demarcate urban municipal boundary could reveal.

\subsubsection{The Impact of Loosely Demarcated Areas Found at the Town Infringes}

This section induces the effect or impacts which would result through lack of having well defined or demarcated boundary in the town Shire Inda Silase.

Table-4.6. the results happen due to absence of demarcated boundary.

\begin{tabular}{|c|c|c|c|c|c|c|c|}
\hline \multirow[t]{2}{*}{$\begin{array}{l}\text { R. } \\
\text { No. }\end{array}$} & \multirow[t]{2}{*}{$\begin{array}{l}\text { The degree of impact of } \\
\text { having loosely demarcated }\end{array}$} & \multicolumn{2}{|c|}{$\begin{array}{l}\text { Respondents sampled } \\
\text { from the residents who } \\
\text { live around at the edge } \\
\text { of the town. }\end{array}$} & \multicolumn{2}{|c|}{$\begin{array}{l}\text { Respondents from } \\
\text { workers of Shire Inda } \\
\text { Silase Municipal office }\end{array}$} & \multicolumn{2}{|l|}{ Total } \\
\hline & & Frequency & $\begin{array}{l}\text { Percentag } \\
\text { e }\end{array}$ & Frequency & $\begin{array}{l}\text { Percenta } \\
\text { ge }\end{array}$ & $\begin{array}{l}\text { Frequen } \\
\text { cy }\end{array}$ & $\begin{array}{l}\text { Grand } \\
\text { percentag } \\
\text { e }\end{array}$ \\
\hline 1 & $\begin{array}{l}\text { Boundary disputes among } \\
\text { the two administrations }\end{array}$ & 4 & $3.88 \%$ & 2 & $9.52 \%$ & 6 & $4.84 \%$ \\
\hline 2 & $\begin{array}{l}\text { Result in Sprawl or } \\
\text { physical expansion }\end{array}$ & 4 & $3.88 \%$ & - & - & 4 & $3.23 \%$ \\
\hline 3 & $\begin{array}{l}\text { Damaging the life of Peri- } \\
\text { urban farmers, the } \\
\text { environment and the } \\
\text { ecosystem }\end{array}$ & 5 & $4.85 \%$ & - & - & 5 & $4.03 \%$ \\
\hline 4 & All & 65 & $63.11 \%$ & 11 & $52.38 \%$ & 76 & $61.29 \%$ \\
\hline \multicolumn{2}{|c|}{ Total } & 78 & $75.73 \%$ & 13 & $61.90 \%$ & 91 & $73.39 \%$ \\
\hline \multicolumn{2}{|c|}{$\begin{array}{l}\text { Those who say shire has } \\
\text { boundary }\end{array}$} & 25 & $24.27 \%$ & 8 & $38.10 \%$ & 33 & $26.61 \%$ \\
\hline \multicolumn{2}{|c|}{ Grand Total } & 103 & $100.00 \%$ & 21 & $100.00 \%$ & 124 & $100.00 \%$ \\
\hline
\end{tabular}

As we can understand from the tabular description above, 91 or $73.39 \%$ of the actual respondents who know as Shire doesn't have boundary which enables to separate its administrative jurisdiction from the neighbouring area or administrative area, tried to tell us how the lack of having boundary demarcation puts an effect to the town for boundary disputes, physical expansion, and damaging the life of the Peri-urban farmers.

So as to add more, A/to Fisha Wubet (Mayor of Shire Inda Silase town) explained that "once there was a demarcation processes taking place on 2011 while we had revising the existing plan, however due to the existing poor implementation and monitoring system it fails. As a result, many problems like illegal expansions, planning overlap, and conflicts in between us (the two administrations".

Beyond this there were other problems also resulting through absence of boundary in Shire Inda Silase. Such as confusions like where to get exactly housing ownership permit and as a result adhere to illegal way of owning progresses (see the following table).

Table-4.7. The administration jurisdictions for which the households pay taxes.

\begin{tabular}{l|l|l|l}
\hline R. No. & Number of Households which get housing ownership title from... & Frequency & Percentage \\
\hline 1 & Shire Inda Silase Municipal administration office & 70 & $67.96 \%$ \\
\hline 2 & Surrounding Rural wereda or 'wereda Lailay Koraro” & 33 & $32.04 \%$ \\
\hline \multicolumn{2}{l}{ Total } \\
\hline
\end{tabular}


As we can refer from the above table, $70(67.96 \%)$ of the respondents address as they can't get the legal housing ownership title from the Shire Inda Silase Urban Development and management department. The remained $33(32.04 \%)$ reflects that they get their house ownership title from the rural 'wereda' administration land development and management office or through other different mechanisms. Those households, who own land or houses out of the permission of Shire inda Silase municipal office, could get their houses through different mechanism See the Figure 4.9 below.

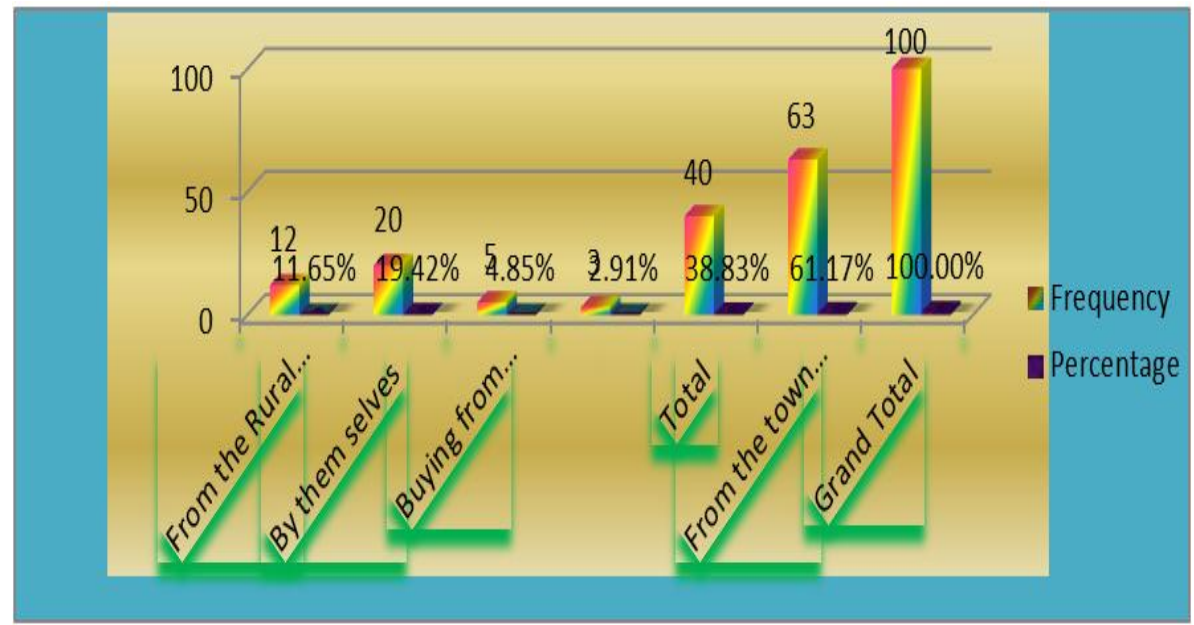

Figure-4.9. Mechanisms of Land Acquisition.

Source: Field Survey 2013.

From the above data in Figure 4.9; we can understand that 10 (9.71\%), $15(14.56 \%), 5(4.85 \%)$, and $3(2.91 \%)$ total $33(32.33 \%)$ of the total sampled household heads answer that they hold the house they owned by other different mechanisms. For instance: through conquest themselves, by permit hold from rural 'wereda' administration office, buying from the surrounding farmers.

Beyond this, there were also other confusions resulted through, absence of having demarcated boundary. Such as: a large share of the respondents didn't know where they should pay taxes, vote their leaders, and totally didn't know where to get all services see Table 4.8 below.

Table-4.8. Households' confusions regarding to paying taxes, getting justice services.

\begin{tabular}{|c|c|c|c|c|c|c|c|c|c|}
\hline \multirow[t]{2}{*}{$\begin{array}{l}\text { R. } \\
\text { No. }\end{array}$} & \multirow[t]{2}{*}{$\begin{array}{l}\text { Types of } \\
\text { Service }\end{array}$} & \multicolumn{2}{|c|}{$\begin{array}{l}\text { Number of Households } \\
\text { pay taxes on Shire FRO }\end{array}$} & \multicolumn{2}{|c|}{$\begin{array}{l}\text { Number of } \\
\text { Households pay taxes } \\
\text { on rural 'wereda' FRO }\end{array}$} & \multicolumn{2}{|c|}{$\begin{array}{l}\text { Those who didn't pay } \\
\text { tax }\end{array}$} & \multicolumn{2}{|l|}{ Total } \\
\hline & & Frequency & Percentage & Frequency & $\begin{array}{l}\text { Percenta } \\
\text { ge }\end{array}$ & Frequency & $\begin{array}{l}\text { Percent } \\
\text { age }\end{array}$ & $\begin{array}{l}\text { Freque } \\
\text { ncy }\end{array}$ & $\begin{array}{l}\text { Percen } \\
\text { tage }\end{array}$ \\
\hline 1 & $\begin{array}{l}\text { Regarding to } \\
\text { Taxation }\end{array}$ & 51 & $49.51 \%$ & 19 & $18.45 \%$ & 33 & $32.04 \%$ & 103 & $100 \%$ \\
\hline 2 & $\begin{array}{l}\text { Regarding to } \\
\text { justice service }\end{array}$ & 59 & $57.28 \%$ & 44 & $42.72 \%$ & - & - & 103 & $100 \%$ \\
\hline
\end{tabular}

From the table presented above out of the general number of households (86) who were pay taxes regularly, $60(69.77 \%)$ paid the taxes on Shire Inda Silase finance and revenue offices, whereas, the remain 26 (30.23\%) paid their taxes on the rural wereda administration 'wereda Tahitay Koraro' . The rest 33 (32.04\%) didn't pay taxes. Reasons which they suggest were some of them didn't know where to pay, some of them, refuses paying taxes, some of them were a rented households. This indicates that though they are found within the same area, they haven't clear information about where should they get their rights and in turn pay back their duties.

As we can see from the above table, those households also didn't distinguish from which justice provision institutions they should serve the justice service. This means $78(62.9 \%)$ of the households live at the area of urban infringe, did says they should serve it from Shire Inda Silase Town where as the remained 46 (37.1\%) did say they should get it from the rural wereda administration. 
Table-4.9. the degree of knowledge of households on recognizing where they should supposed to get all kind of services.

\begin{tabular}{l|l|l|l}
\hline R. No & Degree of knowing where shall to get all type of service & Frequency & Percentage \\
\hline 1 & Yes 'I know' & 72 & $69.90 \%$ \\
\hline 2 & No 'I didn't know' & 31 & $30.09 \%$ \\
\hline \multicolumn{2}{c|}{ Total } & 103 & $100.00 \%$ \\
\hline
\end{tabular}

Source: Researchers Field Survey, 2013.

Based on the respondents' response on the above Table 4.9, $80(65.52 \%)$ of the sampled households only know exactly where they should suppose to get services of all kind, where as the remained 44 (35.48\%) didn't know exactly where.

From the review literature in which the researcher review in chapter two, having not well demarcated boundary costs a sprawl. Sprawl, according to (Robert, 2005 Cited in Mohammed and Suleiman (2006)) in his book 'a compact history' in turn costs for different problems. Among the many problems some of them are discussed below:

- It puts danger to aesthetic values;

- Environmental problem;

- Questioned to Social Concern;

- Destruction of farm land and open space;

- Automobile dependence

-As the above tabular description in Table 4.8 \& Table 4.9 tells as, the responses of the respondents also proofs that lack of having a well defined boundary in Shire Inda Silase also costs the same problem. In addition, those households who live around the edge of a town had not all get their house ownership title from the town administration of Shire Inda Silase.As Isaac (2009) discussed The land use right disputes have been going to become too much worse than ever specially at the urban boarders in areas where the use and administration of that particular land is found belongs to the rural areas, as far as housing issue had been going more critical to the existence of each citizens of the country. For instance: In Jima town there is a series conflict between the municipality and the displaced farmers from their farmland because of urban expansion.

In addition, according to the Ethiopian land administration policy, towns could effectively administer their scarce land resource and could lead overall socio-economic issue of their towns, if and only if they could be able to have clear administrative boundary demarcation (MoUDC, 2013: Amharic version). According to this directive model (MoUDC, 2013: Amharic version) towns or cities could also use their land resources effectively, if and only if they be able to identifying and registering their land resources found under their administrative Jurisdiction. The data in which the researcher gets from the respondents shown on Table 4.6, Table 4.7, Table 4.18, and Table 4.9 also demonstrates the same problems could happen on Shire Inda Silase town administration due to having loosely demarcated boundary. The above data also try to show us that lack of having well demarcated boundary costs the Shire Inda Silase town administration and its residences as well as the workers of the municipal administration office of the town to faced with problems like the above stated by the different scholars.

\subsubsection{Trends of the Shire Inda Silase's Ulgas Employees (Workers of Land Department) Made on} Addressing the Problem of Boundary Issue

In this case, the researcher collects the response of all respondents through an open-ended question (see question-7 in appendix: 7.1, instruction-III). Majority of those respondents (from both parts) revealed that many a time workers of the Shire Inda Silase Municipality office doesn't adhere through proactive measures while they deal with the problems faced in their works. The respondents hardly appreciate the workers for their counter response on giving awareness for the households on which house or parcel, whom household, and which area exactly is belongs to the town administration. According to their responses respondents' hesitating much to the workers of the municipality of Shire Inda Silase even to the extent of doubting that they can know where the particular house hold pays tax whom they give construction permit See, Table 4.11.

Moreover, the respondents try to elaborate that the workers of the municipality or other development stakeholders (such like NGOs, the development government agents, the urban development and construction bureau of Tigray, etc) of the town were observed to track against the problem (like dispute raising as a result of absence of boundary demarcation) after it obviously happen. They didn't lay a precondition for protecting problems presupposed to be happening before they stack on the ground. In addition it is habitual also to observe them in deal over one problem only, by letting aside other works. They are most of the time stand for waiting orders from the above for to do something rather than taking best practices and try to apply by scale upping it in to the context of their working environment. They are, according to the responses get from the respondents, also adapted to routine activities rather than adopting new innovations and new work styles. They intend more to be ridged for new laws and directives. 
So, the researcher from the responses of respondents can understand that, the main problem for which the boundary demarcation issues left aside was because of the weak collaboration and cooperation trend of the workers and offices of both 'wereda' administrations.

\subsubsection{Factors Which Causes for Delayed Demarcation Processes}

In this case, the researcher had collect the data through an open ended question for both respondents and haven't any numerical additions and countable frequencies. But from their responses almost more than half of them describe as what reasons or factors that puts a delay till this time. According to the responses of the workers of the ULGAs, Urban land development and management department unit, the following are the major factors make the delay of the demarcation processes. These are:

\section{Lack of concern and enforcing mechanisms/directions from the head government organs/offices towards the issue of boundary in the past times:}

According to the respondents' suggestion, there was no strong enforcing mechanisms or directions from the federal (such as the urban development and construction ministry), or regional government organs or office which made the the Shire Inda Silase city administration to lounge early for boundary demarcation processes. This means, in past years there were no directions or new frame works given by government starts marching for demarcating boundary of towns and cities. Because of this, the Shire Inda Silase town administrative officials abandoned the issue of boundary to look after all their works and to consider themselves as they are not counted to the problems happen following it.

II. Lack of having an early over sight on the problem happen due to having well demarcated boundary:

Many a time, as the respondents discuss, the workers of the shire municipality office workers the knowledge and anticipation on what would going to happen, if they don't react over the problem happen or they don't want to devote time and effort deal with what is going to happen.

\section{Absence of peaceful dialogue relationship among the two 'wereda' administration and} administrative organs:

This, as the respondents address, make imprisoned both of them not to made a collaborative work in studying, identifying, and dealing with problems (such as double ownership claims).

\section{The prevalence of weak administrative organs in the past time:}

From the response of the respondents it is easy to understand that there had been a week 'wereda' administrative units or organs in the town. The respondents say, as far as there was no strong administration and rules, informal householders are not made to be accountable to their actions it can't make end for the actions of illegal squatters around the town infringe. As a result the town grows horizontally, the rural lands going to conquest through the illegal squatters, then the Peri-urban lands made to be victims of double ownership claims, at the end the life of the farmers and the surrounding environment continued to being the hubs of scenario.

\section{Absence of workers that have compassion and integrity to fight against illegal actions happen at the urban fringe:}

The responses get from the respondents; tell us these workers didn't have motive and courage to fight against the illegal actions of the informal residents. This in turn pleases the informal expansionists to buy, hold by themselves, and fruiting over the land of farmers, as a result contribute to urban expansion horizontally. The horizontal expansion roughed the relationship which might be existed among the two 'wereda' administrations, and then the agreement which supposed to be realized would change to conflict and disagreements. According to Jeffery (2002) the problem of horizontal governance across an extended area confronts all of these urban regions. Settlement and economic activity frequently expand across institutionalized boundaries, and beyond the reach of stable, pre-existing governance arrangements. According to this writer, as the researcher discussed earlier in chapter two, lack of integration between these two 'wereda' administrative organs and the like situations presents several problems. Such as:

- Absence of territorial controls and guidance: Urban spread can be limited and restricted only by cooperative action among the affected urban areas. Local governments must look beyond their parochial vision and strategy, and make at least a minimal effort to acknowledge and accommodate this crucial spill over dimension;

- Shortcomings in management capabilities and experience: Small government units find it difficult to attract and develop the administrative and technical resources required for territorial management. Pooling resources could provide increased efficiency and economies of scale;

- Lack of structural consultation for solving common problems: Collective action by local governments is still there" 
The data from the responses of the respondents (presented above) also showed us that such and the like problems were quite had been happened in Shire Inda Silase municipal administrations due to absence of having boundary demarcations.

\subsection{Major Challenges Drawn from Findings of This Study}

As indicated in the above statement of the problem and objectives of this study, there were considerable challenges hindered to achieve the indicated and desired objectives. To avoid such challenges investigation through researchable system is necessary. That's way this research conducted in such investigation. The researcher's, however, faced with different challenges while conducting this investigation. These challenges were: Rose from some respondents' regarding the way they give responses: this indicates that some respondents didn't fill all questions provided on the questionnaire, some were return unfilled, and some of them were damaged and tear the paper. Of 141 samples of respondents, 10 of them were totally distract the questionnaire that supposed to fill and returned. 7 of them were rejecting filling the questionnaires by responding as they didn't know or hear before about the boundary issue. This made to lower down the percentage of the response. In additions there were also respondents who adhere towards the opposite of demarcation of boundary. The researcher, therefore, holds a little hesitation towards the effective implementation of the plan that the Shire Inda SIlase Municipal administration scheduled to demarcate the boundary of Shire Inda SIlase town.

1. Rose from the quality of response: includes the idea, perspective, or knowledge in some area of the respondents were much tackling to the investigation. Some respondents had not committed to fill all the questions (specially the open-ended questions) so that the researcher found difficulty to understand the reasons for why they say in the first questions.

\subsection{Summary}

As the researcher understands from the responses of the respondents and the findings in general, lack of having well defined and demarcated boundary endures a lots of multi-faceted problems in Shire Inda Silase Town. Or on the other side the investigation shows, though there were some views of the people that hinders development of the town without understanding what development of a town looks like, determining one's administrative boundary and know what are the areas found or administer to its administrative jurisdiction could put a multi-faceted positive impact to a town, perhaps specially to Shire Inda Silase.

\section{Conclusion and Policy Implication Based Recommendations \\ 5.1. Introduction}

This chapter consists of the conclusion drawn from important findings and possible recommendations forwarded mechanisms or means for solving or to put directions for tackling towards the challenges identified by this study under the specific objectives.

\subsection{Conclusions}

Ethiopia at this time, though it starts ratifying and approval processes it didn't pretending much to the extent of stopping and combating the problems happened due to lack of demarcating the boundary of its towns and cities (MoUDC, 2012; Amahric Version). Boundary, according to on line dictionary, is a Line determines the limits of an area, bound or edge. An urban boundary, in this context, refers to a line specify the limits of an urban or an entity that specifies an area called urban with its contemporary areas surrounded such as urban area, rural farm land area, and barren or forest area. Urban administrative boundary is a demarcation which separates the entity called Urban from its surrounding it. The necessity for having a demarcations or having an administrative boundary bears an important benefits both to the town administration as well as the surrounding entity (On line dictionary). Municipal Administration boundary, as Pendell et al. (2002) denotes the edge of an urban service area and is denotes a line beyond which a city has decided that its infrastructure typically sewer and water - should not extend. Having this kind of demarcation, for a town encourages it for getting higher density and infill development within the urban boundary areas, while helping to maintain the rural character of areas lying outside the boundary. Absence of Municipal boundary had come as a major concern of the city managers, planners and environmentalist as to what extent that cities should expand horizontally this day. It had been come as familiar that cities of this time intended highly to constrain their horizontal growth by shifting their development tendency for infill and upgrading developments. This is because of the reasons that horizontal expansions and developments came as damaging for the Peri-urban farmers, the farmland and the surrounding environment and the ecosystem in general. Having put this in mind, today's trend of cities and towns of this time highly advocates against sprawl and exercising demarcating their boundary and intended to identify areas of their jurisdiction.

Though we are late beginner, Ethiopia also found in the way of ratifying and policy directives. Shire Inda Silase which the research study area, also in the way of demarcating its administrative boundary but not yet. Lack of having this demarcations, Shire Inda Silase accommodates a lots of boundary related problems. Taking this in advance the researcher pretends his knowledge and time to investigate on this problem by reforming a 
title "Determining urban boundary and its out coming impact on land administration". The researcher was set out an objective (general and specific objectives) and plans to investigate on the existed problem. The researcher were review an important and related literature to find the gap and really to know or learn about the trends which other developed or developing country goes through to address the like problems faced before. The researcher after that sets or plan different best suited methodology or mechanisms which enable him to conduct a good investigation on the problem prevailed on the Shire Inda Silase town.

Based on the plan the researcher gone to the area of the study and devote time and resource and in turn collect relevant data around the issue of boundary and the related problems happened at Shire Inda Silase. Based on the data collected from primary and secondary sources; the researcher presented and discussed the finding investigated on the research area. According to the investigation the following are the conclusions derived from the general findings of the investigation. These are:

- There is no well defined and demarcated boundary which can serve the town from conflicts happened due to competing and conflict interests happen in the area around its edges;

- The knowledge and perspective of the households is good at providing good foundations for conducting demarcation processes if in case the town administration with the neighbouring area administration plan to demarcate its jurisdictions in future;

- There were a misunderstanding in between the two administrators and confusion in the households live on the edges of a town for which they should devote the responsibility acquired from them and in turn enjoys their rights. Such as paying taxes, vote in election, get justice service, and totally from which they could serve the social services;

- There had been a weak integration and network in between the two 'wereda' administration in controlling and ratifying a double land ownership over the same area, especially at households live the town infringes;

- As far as there were no fixed boundary, continuous expansion or town sprawl get increasing over and over damaging the life of the Peri-urban farmers, farmland and the environment had happened:

- The experts and professional workers of the Shire Inda Silase had been faced difficulty in administering and monitoring the households found in their area. This is because there had been a continuous increase in the constructions of houses and expansions at those area;

- Continuous interrogation and suing each others had been increasing among the two 'wereda' administrations;

\subsection{Recommendations}

Based on the data analysis and presentation, researcher's personal observation, different documents about boundary demarcation and related issues, interviews, and questionnaires, the following key measures are recommended to reduce the challenges and ending the problems forever as well as results for sustainable development of urban life in the study area. These recommendations are locally appropriate enough, when ever applied, to minimize and thereby alleviate the existing challenges that hinder the possibilities of creating peace full and conflict free governance relationship in between the two 'wereda' administrations. These in turn, are necessary potentials for better development, protection and beautifying the town in which sustainable, environmentally sounded development will be easily realized.

5.3.1. Create Awareness on the Workers of the Ulgas Unites Perhaps Especially on the Workers of ULDM Department, People, and Other Stakeholders about the Advantage of Having A Demarcated Boundary for their Town

The need to make this is; first, so as to help the people avoid their ambiguity about making a boundary doesn't mean a containment of the growth of the town. It is rather to make control for the problems resulted through illegal expansion, conquest and over claim double ownership on the same area, and etc. by making this then make increase a participation of people over the work and in turn make them to be marched as a guardian for protecting the illegal expansionists, such as illegal construction of houses like what they called "yechereka house". In addition, this helps to create smooth relationship share best practice each other's they have among the two 'wereda' administrations and administrative organs.

5.3.2. Make an Inventory by Collaborating Agents from Both Wereda Administrations upon Whom Residents and their House (or which Parcel in General), Would Found within the Rural are Jurisdiction as Well as on Shire Inda Silase Town Jurisdiction One by One:

Making this helps for both of them so as to know: who and which is belongs to their administration jurisdiction, enables them to review how much number of new tax payers added to their jurisdictions, and also help them to make a clear images for the total condition of residents found on the edge of the town. 


\subsubsection{Make a Clear Well Defined and Well Fixed Boundary as Soon as Possible}

As the researcher try to address in chapter four, there is a beginning processes for demarcating the the administrative location of Shire Inda Silase. Starting processes like recruiting committee, study the problems happen related to the past uncontrolled boundary cases. But the ongoing processes and efforts had been making aren't satisfactory.

The researcher recommends that by collaborating efforts from both the 'wereda' administration such like meting and seating face to face for discussion and consensus what should be best for both of them. Then after identify boundary case related problems resulted by each of them one by one. Then after make a brute less agreement for to bring an end for these problems. For instance: taking a measure for abolishing illegal resident of the town reside on the land or area located within the rural administration jurisdiction.

\subsubsection{Measure the Total Area or Circumference of the Town and Measure what Amount is Remain for} the Rural Administration:

This helps for both of them to know: one over what amount of square K.M are their administrative jurisdiction area is; second, to let a precondition for protection in case one of them would try to cross over their jurisdiction could easily sue and ask for further procedures, and finally to look after what survives would be there, what remains and what shall have be done for it?

\subsubsection{Laid on a Precondition Policy for Protecting over Cross Responsibilities Probably will Happen} against the Agreements they Made

This agreement helps to adhere and bind over their actions as such keeping their foot after the demarcated area.

5.3.6. Make a Mark that Can Be Seem to as Such as Pinching Pillars, Fencing Walls, or Other Point that Can Be Easily Seen and Understand by Others

This enables for anybody who can stick over the activities of tax in, providing a service etc. For instance in case a new employee who works on the land department comes.

5.3.7. Draw and Hold a Thematic Map Which Can Clearly Show the Demarcation Points and Hold at Hand or in any Other Easily Accessible Mechanism, Such as on Electronic Sources

This is for the purpose of making easily accessible for others who need to know about it and in turn provides some services or for those who want to invest their money and capital in the town. That means making a good protection for those residents found at the edge of the town from the future conflict and misunderstandings on boundary.

5.3.8. Create Employees and Managers that Have Positive Developmental Attitude as Well as Strong Organizational Structure that Can have Greater Role in Implementing Direction Put through the Minister Offices and Regional Bureaus

The Shire Inda Silase ULGAs should have work much on changing the attitude, capacity and skill of its workers and in turn help them adapt and deal with new policies, strategies, and new technologies and innovations.

5.3.9. Strengthen the Relationship of the Two Wereda Administrations Started with Formulating a Committee to the Extent of Conducting an Inventory of the Rural Wereda Agricultural Land

This helps to both administrative organs so as to know or identify what land and which households is found at the near adjacent edge of the town and at the beginning of the rural wereda administration. This in turn helps so as to protect illegal expansionists and informal settlers who try to escape from the law by lying one time to the rural wereda as they get the land from the urban wereda; some other time, to the urban wereda as they get from rural wereda administration.

\subsection{Conclusions}

This chapter includes the introductory part and continued by the conclusion which sum up the four chapters (Chapter 1 to 4). After that it preceded by the recommendations which provided the possible solutions for the challenges indicated in this investigation in detail. Generally, recommendations regarding to the loosely demarcated boundary or the impact of loosely demarcated boundary and its impact, the existed condition and trials made on demarcation processes, the major challenges drown from findings of this study are the main points or issues discussed on this chapter.

\section{References}

Auckland Council. (2012). Auckland plan committee: Defining the rural urban boundary file No.: CP2012/12071. Retrieved from www.aucklandcouncil.govt.nz/.../committees/aucklandfuturevisionco. [Accessed December 15, 2012]. 
Bagchi, P. (2012). Urban growth boundaries: Check urban sprawl. Zimbio India. Retrieved from www.zimbio.com/.../Urban+Growth+Boundaries+check+urban+spra. [Accessed December 18, 2012].

Bhatta, B. (2010). Chapter 2: Causes and consequences of urban growth and sprawl; analysis of urban growth and sprawl from remote sensing data, advances in geographic information science, Available at: 10.1007/978-3-642-052996_2, C Springer-Verlag Berlin Heidelberg 2010. Retrieved from file https://www.springer.com/cda/content/document/cda downloaddocument/9783642052989c1.pdf? SGWID=0-0-45-876948-p173940766.

Central Statistical Agency Addis Ababa. (2012). Ethiopia demographic and health survey: 2011. Ethiopia ICF International Calverton, Maryland, USA. Retrieved from https://dhsprogram.com/pubs/pdf/fr255/fr255.pdf. [Accessed January 23, 2013].

David, O. (2006). City Limits: Walking Portland's boundary. Corvallis: Oregon State University Press, 2006. 125 pp: 18.95 (paper). Mr. Robert Cruikshank (Department of History, University of Washington) Published on H-Urban (November, 2006). Retrieved from www.h-net.org/reviews/showpdf.php?id=12551. [Accessed December 15, $2012]$.

Deborah, K., \& Tadesse, E. (2006). Deepening decentralization in Amhara regional state and Tigray national regional state and restructuring of nine urban local governments: Shire Indaselassie performance improvement plan. Up project no. 07806-000.the urban institute $2100 \mathrm{~m}$ street, NW Washington, dc 2003. 7(202), 833-7200.

FHWA. (2003). Urban boundary \& federal functional hand book: Transportation statistics office Florida department of transportation $\quad$ Tallahassee, $\quad$ Florida. $\quad$ Retrieved from www.dot.state.fl.us/planning/statistics/hwysys/fchandbook.pdf. [Accessed December28, 2012]. Growth, \%20Lessons\%20from\%20Portland.pdf. ‘Accessed December 18, 2012].

Ian, P. W. (2001). Land administration "best practice" providing the infrastructure for land policy implementation. Department of Geometrics, The University of Melbourne, Victoria 3010, Australia Received 24 November 2000; received in revised form 19 March 2001; accepted 20 March 2001. Retrieved from http://citeseerx.ist.psu.edu/viewdoc/download?doi=10.1.1.471.9667\&rep=rep $1 \&$ type $=$ pdf.

Iestyn, W., Helen, D., \& Suzanne, R. (2010). Joined-up rationing? An analysis of priority setting in health and social care commissioning. Retrieved from http://citeseerx.ist.psu.edu/viewdoc/download? [Accessed January 23, 2013].

Isaac, A. (2009). An assessment of the negative impacts of urban expansion on the livelihoods of small-scale farming households; the case of Jima town. Urban Management Program in Partial Fulfillment of the Requirements for the Award of a Masters Degree. Ethiopian Civil Service University.

Jeffery, S. (2002). Metropolitan governance: United cities and local governments. Retrieved from www.citieslocalgovernments.org/gold/.../09_metropolis_en.pdf. [Accessed January 27, 2013]

Kiyako, Y. (2012). Evaluation of the degree of the sufficiency of public green spaces as an indicator of urban density in metropolitan areas in Japan the Chubu Metropolitan Area. Retrieved from http://ww.citeseerx.ist.psu.edu/viewdoc/download?doi=10.1.1.429.945\&rep=rep 1.../pdf.

Kothari, C. R. (2004). Research methodology: Methods and techniques: New Age International.

LiulSeged, K., Gete, Z., Dawit, A., Fitsum, H., \& Andreas, H. (2011). Impact of urbanization of Addis Ababa city on periurban environment and livelihoods: The case of Addis Ababa. Retrieved from www.efdinitiative.org/.../...

Marin, M. C. (2007). Impacts of urban growth boundary versus exclusive farm use zoning on agricultural land uses. Urban Affairs Review, 43(2), 199-220.

Marquardt, W. H., \& Crumley, C. L. (1987). Theoretical issues in the analysis of spatial patterning. Regional Dynamics: Burgundian Landscapes in Historical Perspective, 1-18.

Ministry of Urban \& Construction (MoUDC; Amharic Version). (2012). Urban land management policy /Amharic Version/. Addis Ababa, Ethiopia. Unpublished.

Ministry of Urban Development \& Construction (MoUDC; Amharic Verions). (2013). Ministry of urban and construction: Urban boundary demarcation and land resource inventory directive model /Amharic version/. Addis Ababa, Ethiopia; Unpublished.

Mohammed, H. A., \& Suleiman, M. (2006). The causes and consequences of the informal settlements in Zanzibar. Shaping the Change XXIII FIG Congress Munich, Germany, October $8-13$, 2006. Retrieved from www.fig.net/pub/fig2006/papers/.../ts35_01_ali_Suleiman_0320.pdf. [Accessed January 24, 2013].

Nial, F. (2005). The archaeological landscape of the shire region, Western Tigray, Ethiopia. Annalee d' Ethiopie, 2005, vol.xxi: 7-29. Retrieved from www.persee.fr/web/.../ethio_0066-2127_2005_num_21_1_1091. [Accessed December 11, 2012].

Pendell, R., Martin, J., \& Fulton, W. (2002). Holding the line: Urban containment in the United States. Brooking Institute centre on urban and metropolitan policy. Retrieved from Http://www.fsu.edu/ localgov/.../Pendell_Fulton_Urban_Containment/pdf/. [Accessed December28, 2012].

Pierre, B. G. P. J. (2003). Handbook of public administration: Sage.

Queensland Government. (2016). Working together for better housing and sustainable communities: Discussion paper. It's time to take action; message of the Minister. Retrieved from http://www.hpw.qld.gov.au/SiteCollectionDocuments/HousingDiscussionPaper.pdf. [Accessed January 23, $2013]$.

Reid, E., Rolf, P., \& Don, C. (1990-2000). Measuring sprawl and its impact: Volume I. Retrieved from https://smartgrowthamerica.org/app/legacy/documents/MeasuringSprawlTechnical.pdf. [Accessed Juanuary, $23,2013]$.

Samuel, R. S., \& Gerard, C. S. M. (1999). Urban-growth boundaries and housing afford-ability: Lessons from Portland. 3415 S. Sepulveda Blvd., Suite 400 Los Angeles, CA 90034 (310) 391-2245. Retrieved from www.buildingthepride.com/.../Article\%20\%20Managing\%20Urban\%20.

Serryn, L. E. (2002). GIS applied to administrative boundary design Submitted in total fulfillment of the requirements of the degree of Ph. D. Department of Geometrics Faculty of Engineering the University of Melbourne. Retrieved 
from http://www.csdila.unimelb.edu.au/publication/theses/Serryn-Phd_Thesis.pdf. [Accessed January 24, 2013].

Sewunet, A. (2008). An analysis of the effects of urban expansion on environment: The case of Debre Markos. Addis Ababa, Ethiopia.

Simon, C., Frati, F., Beckenbach, A., Crespi, B., Liu, H., \& Flook, P. (1994). Evolution, weighting, and phylogenetic utility of mitochondrial gene sequences and a compilation of conserved polymerase chain reaction primers. Annals of the Entomological Society of America, 87(6), 651-701. Available at: https://doi.org/10.1093/aesa/87.6.651.

Smart Growth AmericaRegistered Nurses association of Nova Scotia. (2002). Professional boundaries and expectations for nurse client relationship 2nd edition, By College of Registered Nurses of Nova Scotia (CRNNS). Retrieved from www.crnns.ca/documents/professionalboundaries.pdf. [Accessed January 23, 2013].

South Africa Census. (2001). Concepts and definitions / Statistics South Africa. Pretoria: Statistics South Africa, 2003; Previous title: The people of South Africa: Population census, 1996: Definitions 18p. [Report No. 03-02-26 (2001)]. Retrieved from http://www.statssa.gov.za/census/census_2001/concepts_definitions/concepts_definitions.pdf. $\quad$ [Accessed January 23, 2013].

Staley, S., \& Mildner, G. C. (1999). Urban-growth boundaries and housing affordability: Lessons from Portland. Los Angeles, CA: Reason Public Policy Institute.

Stig, E. (2009). Land administration systems- managing rights, restrictions and responsibilities in land. FIG President Aalborg University, Denmark. Retrieved from https://www.fig.net/organisation/council/council_20072010/council_members/enemark_papers/2009/hyderabad_enemark_paper_feb_2009.pdf. [Accessed January 24, 2013].

Terrier. (n.d). Moments of boundary research: A long-term perspective. Retrieved from https://ecpr.eu/. [Accessed January 23, 2013].

UN-Habitat. (2008). Secure land rights for all: Land resources face multiple pressures and demands as never before, and developing countries still lack the tools, systematic strategies and support necessary to deliver secure land rights for all. Retrieved from https://dlc.dlib.indiana.edu/dlc/bitstream/handle/10535/6047/secure\%20land\%20rights.pdf? sequence=1\&isAll owed $=\mathrm{y}$. [Accessed January 23, 2013].

UN-Habitat. (2012a). Chapter four: Drivers (Determinants) of expansion of fin fine (Addis Ababa) City and the role of actors. Retrieved from http://shodhganga.inflibnet.ac.in/bitstream/10603/22154/13/13 chapter 4.pdf.

UN-Habitat. (2012b). The global urban economic dialogue series: The economic role of cities; First published in Nairobi in 2011 by UN-HABITAT. Copyright (C) United Nations Human Settlements Program 2011 HS/067/11. Retrieved from http://mirror.unhabitat.org/pmss/getElectronicVersion.aspx?nr=3260\&alt=1.

\section{Field Research Plan}

To conduct this research study, every activity needs a scheduled duration .For this reason, the work plan has prepared properly in the following table: Based on this idea, the following table shows the series of activities and time frame of the study.

\begin{tabular}{|c|c|c|c|c|c|c|c|}
\hline \multirow[t]{2}{*}{ No } & \multirow[t]{2}{*}{ Activities } & \multicolumn{6}{|c|}{ The time or months in which activities will performed } \\
\hline & & January & February & March & April & May & June \\
\hline \multirow[t]{4}{*}{1} & Thesis Preparation \& approval & $\operatorname{xxxxxxxxy}$ & & & & & \\
\hline & Planning of research activity & Xxxxxxxxy & & & & & \\
\hline & Literature review & 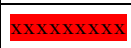 & & & & & \\
\hline & Sample size determination & $\operatorname{xxxxxxxx}$ & & & & & \\
\hline \multirow[t]{5}{*}{2} & Data collection \& tabulation & & $\operatorname{Dxxxxxxx}$ & & & & \\
\hline & Data collection & & $\operatorname{axxxxxxx}$ & & & & \\
\hline & Data entry & & & xxxxxx & & & \\
\hline & Data cleaning & & & & $\operatorname{xxxxx}$ & & \\
\hline & Tabulation & & & & $\operatorname{xxxxx}$ & & \\
\hline 3 & Submission of Chapter One & & & & $\operatorname{xxxxx}$ & & \\
\hline 4 & Chapter two & & & & $\operatorname{xxxxx}$ & & \\
\hline 5 & Chapter three & & & & $\operatorname{xxxxx}$ & & \\
\hline 6 & \begin{tabular}{|l|l|l}
$\begin{array}{l}\text { Initial data analysis submission of } \\
\text { preliminary finding }\end{array}$ & \\
\end{tabular} & & & & \begin{tabular}{|l|}
$\operatorname{exxxxxxx}$ \\
$\mathrm{xx}$ \\
\end{tabular} & & \\
\hline \multirow[t]{3}{*}{7} & Submission of Chapter Four & & & & & $\operatorname{xxxxxx}$ & \\
\hline & Revised Data analysis & & & & & $\operatorname{xxxxxx}$ & \\
\hline & Report writing & & & & & xxxxxx & \\
\hline
\end{tabular}




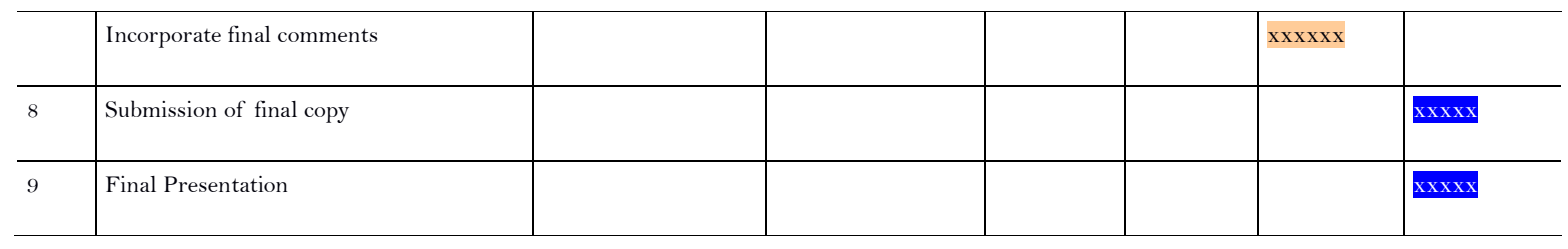

\begin{tabular}{|c|c|c|c|c|c|c|}
\hline \multicolumn{7}{|c|}{ 9.2 Budget } \\
\hline No & Activities & Description of unites & Measure & Unite & $\begin{array}{l}\text { Cost per Unit In } \\
\text { ETB }\end{array}$ & $\begin{array}{l}\text { Total Amount } \\
\text { (ETB) }\end{array}$ \\
\hline \multirow{4}{*}{1} & \multirow{4}{*}{ Proposal preparation } & Printing of internet references & pages & 800 & 0.75 & 600 \\
\hline & & Copy reference books & 450 & & 0.4 & 120 \\
\hline & & Typing and Printing & pages & 41 & 3 & 123 \\
\hline & & Stationeries & different & 5 & 4.5 & 22.5 \\
\hline \multirow[t]{4}{*}{2} & \multirow[t]{3}{*}{ Data Collection } & Typing and writing & pages & $\begin{array}{l}\text { 30(estima } \\
\text { te) }\end{array}$ & 3 & 90 \\
\hline & & Copying of Questionnaires \& checklist & pages & 7 & 0.4 & 2.1 \\
\hline & & $\begin{array}{l}\text { Transport Cost (for taxi) } 3 \mathrm{KM}^{*} 1 / 2 \text { an } \\
\text { hours each day }=6\end{array}$ & hours & 3 & 3 & 9 \\
\hline & & $\begin{array}{l}\text { Costs spent for daily food, bed and other } \\
\text { living costs }\end{array}$ & days & 30 & 70 & 2100 \\
\hline \multirow[t]{2}{*}{3} & \multirow[t]{2}{*}{$\begin{array}{l}\text { Data enumeration and } \\
\text { accommodate }\end{array}$} & To small invitation (lunch invitation) & number & 20 & 70 & 1400 \\
\hline & & $\begin{array}{l}\text { Payment for three Data collectors } \\
\text { Birr } 100 \text { per collector }\end{array}$ & number & 3 & 100 & 300 \\
\hline \multirow[t]{3}{*}{4} & \multirow[t]{3}{*}{ transportation } & Transport & number & 2 & 600 & 1200 \\
\hline & & Per diem 8 days $35 \% * 70=32.00$ & days & 8 & 32 & 256 \\
\hline & & $\begin{array}{l}\text { Research bag that helps containing } \\
\text { research equipment }\end{array}$ & number & 1 & 600 & 600 \\
\hline \multirow[t]{5}{*}{5} & \multirow[t]{5}{*}{$\begin{array}{l}\text { Final thesis paper } \\
\text { preparation }\end{array}$} & Typing and Printing & pages & 70 & 3 & 210 \\
\hline & & Copy of thesis $\left(6^{*} 70\right)$ & pages & 420 & 0.4 & 168 \\
\hline & & Binding & pages & 7 & 15 & 105 \\
\hline & & $\begin{array}{l}\text { Typing and printing power point } \\
\text { presentation paper }\end{array}$ & pages & $\begin{array}{l}40(\text { estima } \\
\text { tion) }\end{array}$ & 3.00 & 120 \\
\hline & & Converting pdfs to words & number & 2 & 20 & 40 \\
\hline \multirow[t]{2}{*}{6} & \multirow[t]{2}{*}{ Miscellaneous costs } & Flesh disk & Number & 1 & 175 & 175 \\
\hline & & Stationeries & Different & 1 & 4.00 & 400 \\
\hline \multirow[t]{3}{*}{7} & & Total cost & & & & 8040.6 \\
\hline & & Contingencies & & & & 2745 \\
\hline & & Grand Total & & & & 10.785 .6 \\
\hline
\end{tabular}

